Proceedings of the Prehistoric Society 84, 2018, pp. 303-327 (C) The Prehistoric Society. This is an Open Access article, distributed under the terms of the Creative Commons Attribution licence (http://creativecommons.org/ licenses/by/4.0/), which permits unrestricted reuse, distribution, and reproduction in any medium, provided the original work is properly cited.

doi:10.1017/ppr.2018.5 First published online 21 June 2018

\title{
The Fields that Outlived the Celts: The Use-histories of Later Prehistoric Field Systems (Celtic Fields or Raatakkers) in the Netherlands
}

\author{
By STIJN ARNOLDUSSEN ${ }^{1}$
}

The Celtic field research programme of Groningen University involves research excavations of Dutch Celtic fields or raatakkers: embanked field plots thought to date to the Iron Age (c. $800 \mathrm{cal}$ BC-12 BC). In this paper, detailed attention is given to (a) the palaeoecology of raatakkers; (b) the relationship between habitation and agriculture in such systems; and (c) their dating and use-life. Counter-intuitively, it is argued that the macroremains from crops such as barley, wheat, millet, and flax recovered from Celtic field banks represent a nonlocal (settlement) signal rather than document local agricultural regimes. Palynological approaches, in which a more local signal can be preserved but which also show evidence for details of the agricultural regime such as manuring strategies and fallow cycles, are argued to be more appropriate avenues to study local agricultural strategies. A discussion of the relations between habitation and agriculture shows that house sites uncovered within Dutch Celtic fields are almost invariably placed in positions partly overlapping banks. Moreover, in most cases such settlement traces appear to date to the Middle or Late Iron Age, raising the question of where the initial farmers of the Celtic fields lived, as the communities planning and first using these Celtic fields probably pre-dated the Iron Age. A critical review of existing dates and discussion of new OSL and AMS dates has shown that bank construction of Dutch Celtic fields started around the 13th-10th centuries cal BC and continued into the Roman era. The chronostratigraphies preserved in the banks testify to a sustainable agricultural regime of unprecedented time-depth: centuries of continued use make the system employing raatakkers the most enduring and stable form of farming known in the history of the Netherlands.

Keywords: Celtic fields, the Netherlands, agriculture, prehistory, field systems, dating

\section{INTRODUCTION: THE PARADOXES OF DUTCH CELTIC} FIELDS

Prehistoric field systems in the Netherlands pose a paradoxical dataset: whilst over 350 locations of such field systems have been mapped (Fig. 1, B), very few of these have been excavated specifically to determine their age, extent, nature, or use-histories. Most of these are systems of embanked fields known nationally as raatakkers and internationally as 'Celtic fields'. Among this large number of known sites, a

\footnotetext{
${ }^{1}$ Groningen Institute of Archaeology, Groningen University, Poststraat 6, 9712ER, Groningen, the Netherlands. Email: s.arnoldussen@rug.nl
}

substantial subset $(\mathrm{n}=168$; Brongers 1976, pl. 10) were discovered on aerial photographs (Brongers 1976, 31-9), which signals yet another paradox: the very fact that these banks were visible in photographs of ploughed fields indicates that their quality of preservation (in terms of analysable sediments) is currently quite limited. For such locations, the potential for analysis of the field plots and banks to unravel agricultural use-histories is significantly reduced because of the levelling caused by agriculture.

Fortunately, an increasing number of new 'Celtic field' locations have recently been discovered following the wider availability and increased resolution of LiDAR imagery. Ranging in scale from several to 

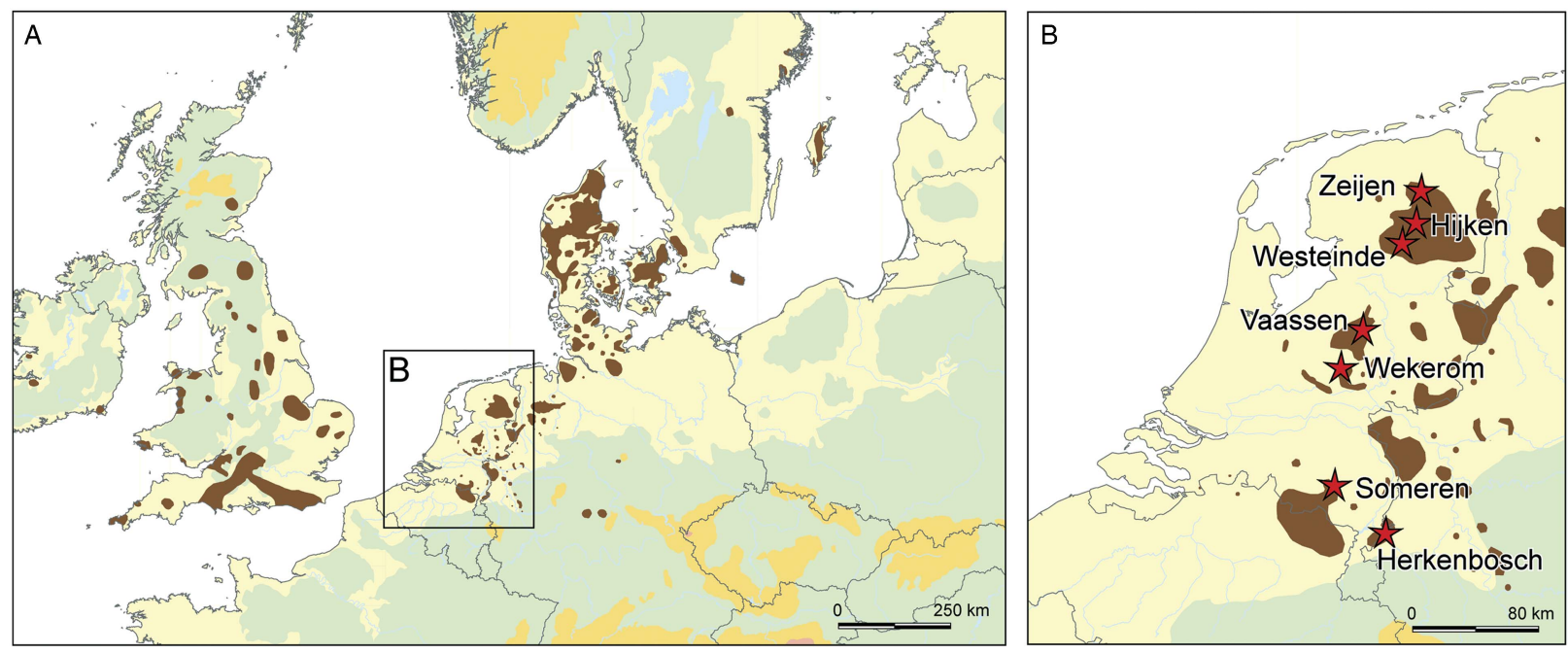

Fig. 1.

Distribution map of later prehistoric field systems (in brown) in north-western Europe (A: after Brongers 1976, 28 , fig. 1 \& Klamm 1993; additions by author), with the locations of the main investigated Dutch Celtic field sites marked as red stars in B

several hundred hectares in size, they support Yates's $(2007,13)$ argument that field systems may represent prehistory's largest - perhaps even monumental (Yates 2007; Cooper 2016, 293) - legacy. Whereas aerial photography helped to discover Celtic fields primarily in cultivated fields, scrutiny of LiDAR imagery yielded a complementary set of Celtic fields in heathland and forested areas (eg, Bewley et al. 2005; Devereux et al. 2005; Humme et al. 2006; De Boer et al. 2008; Kooistra \& Maas 2008; Clemmensen 2010; Hesse 2010; Arnold 2011; Meylemans et al. 2015). In such areas, devoid of recent construction and agricultural activities, banks of Dutch Celtic fields have been preserved up to heights of $90 \mathrm{~cm}$ (Van der Heijden \& Greving 2009, 36). This quality of preservation renders such LiDAR-discovered sites ideal candidates for targeted fieldwork campaigns, in order to shed light on their agricultural role in the past.

This paper argues that we are still very poorly informed on three fundamental aspects of Celtic field agriculture. First, the palaeoeconomy and regional specifics of the agricultural regime responsible for the ubiquitous embanked fields are based mostly on assumptions, as only few sites have seen palaeoecological analysis. Secondly, the traditionally held view that Celtic fields were landscapes used for both habitation and cultivation is similarly based on very few excavated locations and appears to gloss over problems in dating and in the placement of houses with regard to the banks. Thirdly, despite the increase in known Celtic field sites, hardly any efforts have been made to date the start and use-life of Dutch raatakkers directly. In order to redress this imbalance, the results of several recent research excavations of Celtic fields across the Netherlands are presented below, and the extracted evidence on palaeoeconomy, settlement-field interrelations, and dating is discussed. Unfortunately, as the substantial dataset on Dutch later prehistoric field systems up to 2010 did not see much targeted excavation, it has remained problematic to evaluate the Dutch dataset of embanked fields within their wider European context: when did this system come into play in the Low Countries, what inspired it, and how long did it last? How do the Dutch raatakkers fit into the chronologies of later prehistoric field systems on the European and national levels? Ideally, their survival in the contemporary cultural landscape would have sparked more interest in such issues, yet the long but intermittent history of research into Dutch Celtic fields has focused more on mapping than on detailed understanding of the Celtic field phenomenon.

\section{THE DEEP ROOTS OF DUTCH CELTIC FIELD STUDIES}

The earliest reference to what we now recognise as Celtic fields in the Netherlands dates to the 17th century, when the Coevorden vicar Johan Picardt 


\section{S. Arnoldussen. USE-HISTORIES, LATER PREHISTORIC FIELD SYSTEMS IN THE NETHERLANDS}

described and depicted a Celtic field as an encampment of the Suebi tribe. He also excavated one or more sites, as he recounts uncovering a stone-paved area the size of a cartwheel (Picardt 1660, 41-3). This (mis) interpretation of Celtic fields as military encampments was long lived, as the Leiden professor Caspar C. Reuvens visited the 'encampments' (legerplaatsen) of Drenthe in 1819, and again in 1833 (Brongers 1976, 19; Van der Sanden 2009, 17). Reuvens visited several Celtic field sites and had some mapped in detail; he subsequently started to question their interpretation, offering alternative hypotheses, such as they were areas for sheep-management (Brongers 1973, xxxi; Van der Sanden 2009, 17). Reuvens excavated one of these sites (at Exloo), but the results were never published (Janssen 1848, 109; Van der Sanden 2009, 17). The first more systematic examination of a Celtic field plot was undertaken by Leonhardt J.F. Janssen, then curator of the National Museum of Antiquities in Leiden, who dug trenches through the banks and field plots of the Zeijen-Noordse Veld Celtic field in 1848 (Fig. 2, C; Janssen 1848, 110-11). Judging by these trenches, he suspected a Germanic rather than a Roman origin, and - noting their association with barrows (cf. Van Giffen 1939, 88; Brongers 1976, 20; Cooper 2016, 303-5; Ten Harkel et al. 2017, 418) suggested that they might have played a part in funerary rituals (Janssen 1848, 122; Brongers 1976, 23; Van der Sanden 2009, 17), as he found no evidence for their use as settlements, garden plots, or sheep-pens (Janssen 1848, 121-2).

It was not until the first decades of the 20th century that Celtic fields received renewed archaeological attention: between 1917 and 1944, Groningen professor of archaeology Albert E. Van Giffen excavated several 'so-called heathen military camps' (beidensche legerplaatsen - Van Giffen 1918; 1934; 1935; 1940; 1943), although he proposed no clear hypothesis on their function initially (Brongers 1976, 24; Van der Sanden 2009, 19). Taking inspiration from Curwen and Curwen's (1923) and Hatt's (1931) identifications of later prehistoric field systems (as Celtic fields and porsehaver, respectively; Brongers 1976, 24), Van Giffen stated, in 1939, that the Dutch raatakkers or heidensche legerplaatsen were no different, an observation supported by the discovery of post-holes and cultivation traces (spade or ard-marks) in the Zuidveld Celtic field (Van Giffen 1939, 87, 90, 92). Between 1939 and 1941, the National Museum of Antiquities curator, Wouter C. Braat, dug numerous test-trenches through the Celtic field of Wekerom-Lunteren (Fig. 2, E), uncovering a series of plans of Iron Age farmhouses and outbuildings (see Fig. 5, A; Van Klaveren 1986; Arnoldussen \& Scheele 2014, 13-20). The Celtic field of Zeijen-Noordse Veld received most, albeit intermittent, attention from Van Giffen, who excavated this cluster of Celtic fields, barrow groups, and settlement traces between 1917 and 1954 (Brongers 1976, 26; Van der Sanden 2009, 20; Arnoldussen 2012, 20, fig. 13).

As part of his PhD study of Dutch Celtic fields, Ayolt Brongers excavated 0.3 ha of the Vaassen Celtic field (Fig. 2, D), targeting both banks and fields, and uncovering part of an Iron Age house site (Brongers 1976, 44-5). Few other Celtic field excavations were carried out in the second half of the 20th century. An important exception was the excavations at Hijken (Fig. 2, A; Fig. 5, C; Harsema 1991; Arnoldussen \& De Vries 2014), in which the interrelation of Celtic fields with Bronze and Iron Age habitation could be studied. Similarly, an excavation at Peelo-Kleuvenveld uncovered two or three Iron Age house plans amidst the Celtic field plots (Fig. 5, B; Kooi \& De Langen 1987). Yet in general terms, the interrelation of houses and field plots is still poorly understood (Arnoldussen \& De Vries 2017). It would take until the first decades of the 21st century for research specifically aimed at unravelling the Dutch Celtic field use-histories to be published (eg, Spek et al. 2003; 2009; Arnoldussen 2012; Groenman-Van Waateringe 2012; Arnoldussen \& Scheele 2014; Arnoldussen et al. 2016).

\section{PROBLEMATIC DEFINITION: WHAT DO WE NEED TO KNOW ABOUT CELTIC FIELDS?}

I have already argued above that Celtic field research has a considerable time depth, but has seldom explicitly addressed the knowledge gap of their dating and agricultural use. In part, this is understandable from a historical perspective in which focus was first on ascertaining the true nature of this type of site (period c. 1660-1939), and thereafter, attention turned towards a culture-historical analysis of the houses and plots uncovered within them (period c. 1953-1991). Whilst the latter still merits additional study (cf. Arnoldussen \& De Vries 2014; 2017), any new research into the (long term) development of Celtic fields must include efforts to establish Celtic field chronologies (cf. Gerritsen 2003, 174-8).

The generally assumed Late Bronze Age-Iron Age date for Dutch Celtic fields (eg, Spek et al. 2003, 142; 
THE PREHISTORIC SOCIETY
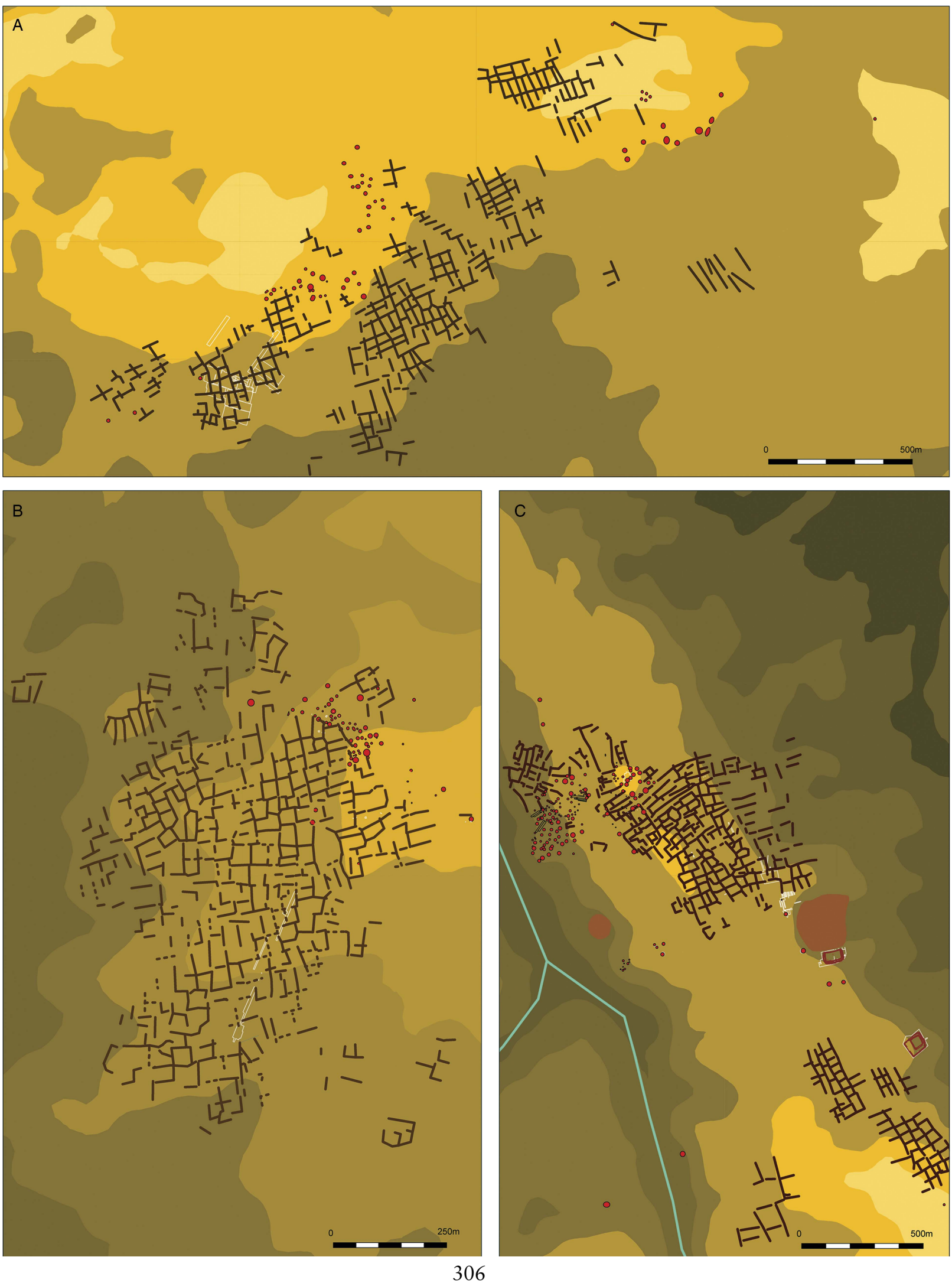

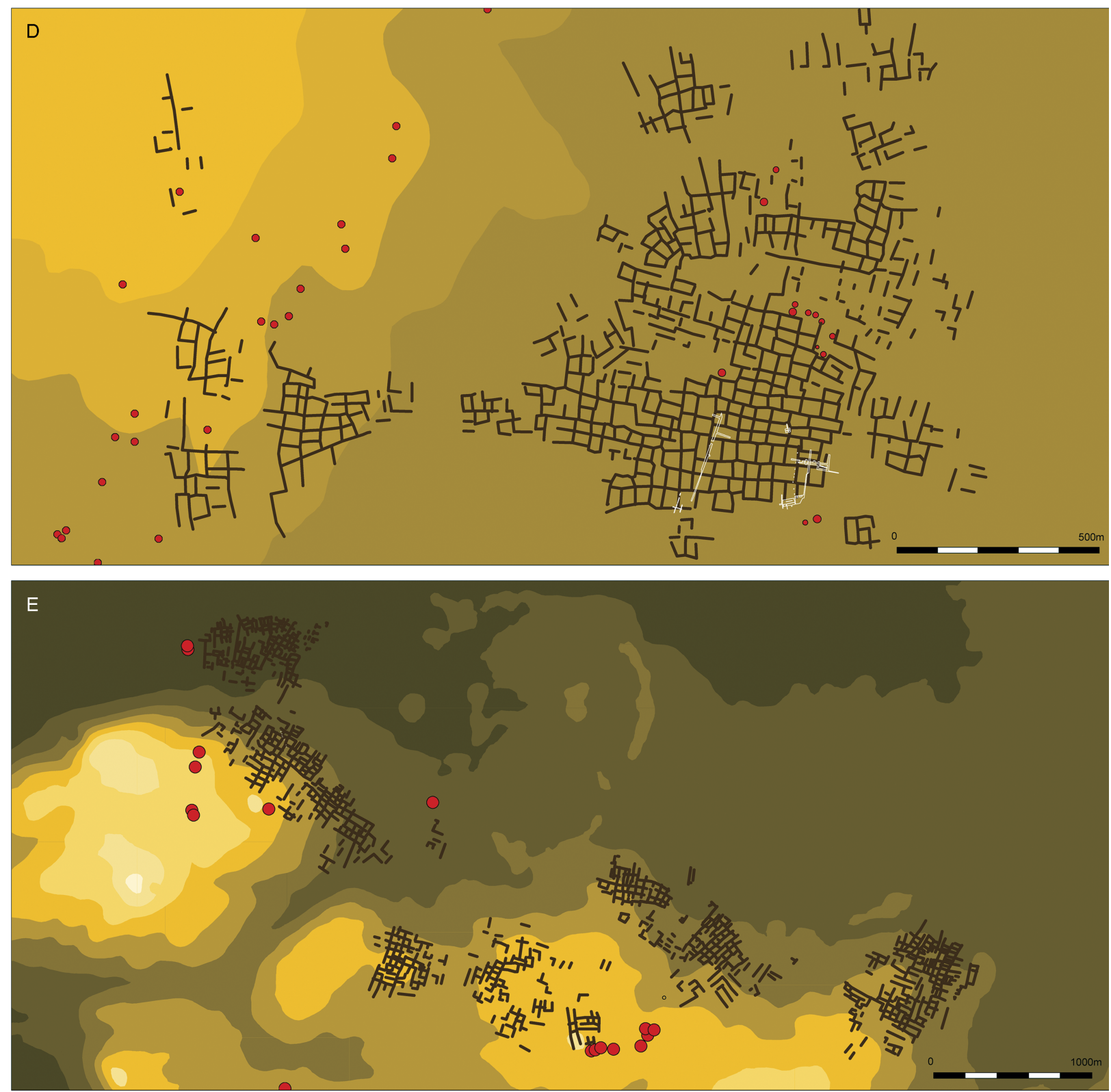

Fig. 2.

Schematic plans of several Dutch Celtic fields. Contours: lower altitudes (brown) to higher locations (light yellow); Celtic field banks as brown polylines; barrows as red circles with black outlines; excavated areas indicated in white polygons. A: Hijken-Hijkerveld (after Harsema 1991; Arnoldussen \& De Vries 2014); B: Westeinde-Noormansveld; C: Zeijen-Noordse Veld (after Van Giffen 1950; Waterbolk 1977; Spek et al. 2003; 2009; Arnoldussen 2012); D: Vaassen (after Brongers 1976); E: Wekerom-Lunteren (after Van Klaveren 1986; Arnoldussen \& Scheele 2014)

Harsema 2005, 543; Kooistra \& Maas 2008, 2319) is often based solely on typochronological characterisation of the pottery or houses recovered in them (eg, Brongers 1976, 64; Waterbolk 1977; Kooi \& De Langen 1987, 55(155), 60(160); Harsema 1991, 29). Where radiocarbon-dated samples are available (Brongers 1976, 52-5, 62-3; Spek et al. 2003, 165), their relation to the encasing sediment and original surface is often unclear, because of the dynamic genesis of the sample contexts (anthropogenic: ploughed fields or 
constructed banks; Waterbolk 1949, 138, cf. Sharples 2010, 36-7). Such problems can only be avoided by using direct dating techniques such as Optically Stimulated Luminescence (OSL; cf. Wallinga \& Versendaal 2013a-b; Voskuilen et al. 2016) or larger numbers of radiocarbon dates that allow us to identify (and omit) anomalies.

Secondly, archaeologists need to focus more on establishing the particulars of the agricultural system in question. Frustratingly, despite there being several hundred known Celtic fields, only very few have been investigated for details of their agricultural system. This means we are poorly informed on (a) the types of crops grown; (b) any use and duration of fallow cycles; (c) materials and frequency of manuring; (d) methods of tillage; and (e) presence and possible dominance of grassland plots versus plots for crop cultivation. Prior research has attempted to tackle such questions mainly through the application of palynology.

An early palynological investigation of the Celtic field layers underlying barrows at Zeijen-Noordse Veld found $1-10 \%$ Cerealia pollen in the samples (Van Giffen 1949, 116, 122; Waterbolk 1949, 140, 143), with indications for hoe-based tillage and waste manuring (Van Giffen 1949, 117, 118, 121). In 1976, the excavations at Vaassen (Fig. 2, D; Brongers 1976) also included palynological studies, but unfortunately only two samples, showing poor preservation, from the Celtic field banks were analysed and showed pollen of Cerealia (0.6-5\% Triticum/Hordeum-type; Casparie 1976, 107-8, fig. 10). Casparie noted the relatively strong presence of grasses and hornworts (Phaeoceros laevis/punctatus; Casparie 1976, 109, 111 ) in these samples, and speculated whether high numbers of herbs reflected bank vegetation or vegetation of fallow fields resulting from multiple-course rotation systems (ibid., 110). The low amounts of ling (Calluna) and beech (Betula), according to Casparie, argued against long fallow periods (ibid., 112). Moreover, high percentages of sedges (Cyperaceae; 8.5$22.1 \%$ ) and spurrey (Spergula; $1.5-15.3 \%$ ) were noted (Casparie 1976, 106-7, table 4). Whereas the latter may have been a crop rather than an arable weed (ibid., 112, cf. Odgaard 1985, 127; Holden 1997, 53), the high amount of sedges could represent introduced wetland sods (used as byre bedding), fodder, or muck manure (Arnoldussen \& Vander Linden 2017).

The palynological investigations of the Zeijen Celtic field in 1993 by Spek et al. (2003, 155-62) started a new phase of research, yet their sample location was much affected by poor preservation (five samples were sterile) and contamination (as shown by pollen of buckwheat washed downwards in the section). Considering only those samples below the deepest levels of contamination, the presence of Cerealia non secale, Secale, and spurrey could be documented. No botanical macro-remains were found, but it is unclear whether any sieving was undertaken to recover such remains. This 1993 campaign should be lauded for its integrated interdisciplinary approach: the same sections investigated palaeoecologically were also studied for their pedology and soil micromorphology, making it possible to postulate that the initial phase of use was marked by an extensive mode of exploitation involving clearance fires, long fallow periods, and manuring (Spek et al. 2003, 164-5, but see Arnoldussen \& Scheele 2014, 58, 86). Moreover, ard tillage of the banks was postulated (Spek et al. 2003, 164). In later (Late Iron Age/Roman period) use-phases of the Celtic field, abundance of pollen in the higher sections of bank was taken to represent less burning and (hence) shorter fallow periods, and high values for grasses and sorrel were taken to indicate that some plots were used for grazing (ibid., 165). Additionally, the latest use-phase showed an influx of organic topsoil or litter from outside the Celtic field and intensification reflected in reduced particle sizes (through more frequent tillage) and increased phosphate content (ibid., 166; but see Arnoldussen \& Scheele 2014, 86 on alternative phosphate distributions).

To sum up the recent inquiries, it remains striking that only very few targeted excavations of Dutch Celtic fields have been undertaken. Consequently, there have remained several problems in the determination of Celtic field chronologies, complicating the pinpointing of the establishment, overall life span, and duration of use-cycles of Celtic fields. Moreover, only a very restricted set of proxies for agricultural parameters such as crop rotation, fallow duration, and manuring regime have been studied for a very restricted set of sites $(n=3)$. These problems prompted the Groningen Celtic fields project.

\section{THE GRONINGEN CELTIC FIELDS PROJECT: THREE SCALES OF STUDY}

In 2012, I initiated the Celtic fields project in order to fill various knowledge gaps in our understanding of long term agricultural landscape development through targeted excavations in Dutch Celtic fields. These were all research excavations undertaken by Groningen 
University and various governmental and heritage partners (ie not developer-led projects), which allowed a research question-driven (rather than location-/developer-driven) approach with flexible planning and detailed sampling strategies. This long term research programme studies Celtic fields on three complementary scales (each with their own pertinent questions).

At the macro-scale, the similarities and differences in form and agricultural use-strategies for Celtic fields situated in different geogenetic settings are studied. Is it that similarities in morphology of embanked field systems across different geogenetic backdrops reflect a highly adaptable agricultural strategy? Or conversely, were communities in different geogenetic regions doing the same despite such differences (cf. English 2013, 15)? To answer these types of questions, a series of excavations of Celtic fields in landscapes of different geological genesis is required. Therefore, Celtic fields have been excavated on Saalian boulder-clay plateaus (Zeijen-Noordse Veld,
Westeinde-Noormansveld; Arnoldussen 2012; Arnoldussen \& De Vries 2017), on Saalian ice-pushed riverine and fluvioglacial deposits (Wekerom-Lunteren; Arnoldussen \& Scheele 2014), on Weichselian coversand deposits (Someren-De Hoenderboom; Arnoldussen 2013), and Middle Pleistocene river deposits underneath a Weichselian coversand layer (Herkenbosch-De Meinweg; Arnoldussen et al. 2014). For these locations, the morphology of the bank systems as well as the composition of excavated fields and banks may be compared.

At the intermediate (meso-) scale, understanding the development and functioning of the individual Celtic field complexes was the primary objective. How did larger complexes (up to 210 ha; Arnoldussen \& Scheele 2014) evolve? Were banks present from the onset (cf. Gerritsen 2003, 174-8) or did they gradually develop? Is there a deliberate interweaving of habitation (house sites) and field plots, as suggested by artists' reconstructions (Fig. 3; cf.
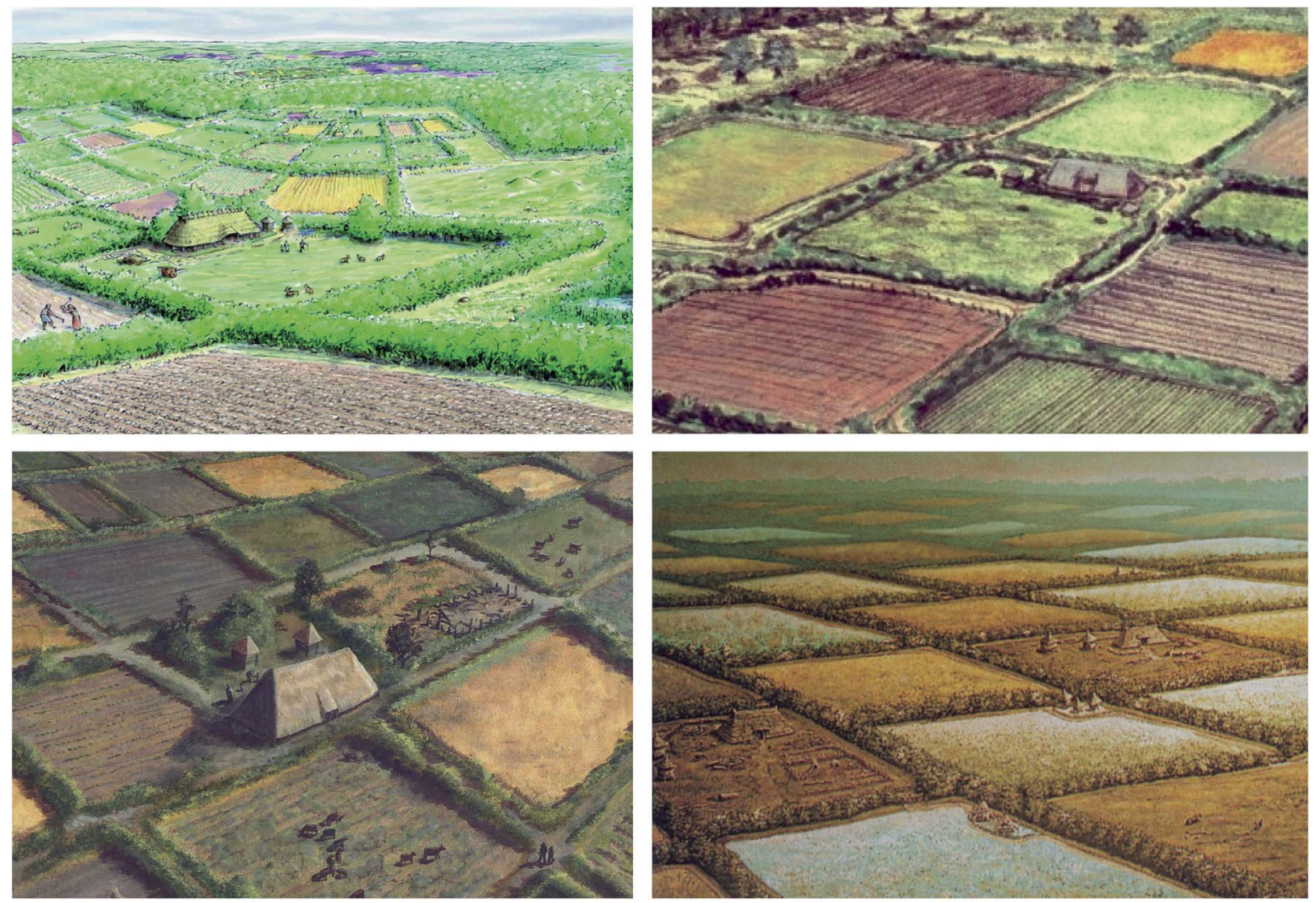

Fig. 3.

Details of artists' impressions of Celtic fields, exemplifying the presumed interrelations of houses and fields. Clockwise from top left: () Gemeente Ede, () Drents Museum, () Provincie Drenthe, () S. Drost 
Arnoldussen \& De Vries 2017), or was this relation more dynamic (cf. Gosden 2013)? Moreover, this is the scale at which the morphological patterns mapped through LiDAR or aerial photography are operationalised into discussions of Celtic field development, Celtic field expansion, and studies of tenurial regimes (cf. Schrijver 2011; Van Wijk 2015).

The micro-scale of the Groningen University Celtic field programme concentrates on reconstructing the age and uses of individual Celtic field plots and banks. This entails careful excavation of different plots and adjacent banks in several parts of a given field complex. By combining traditional archaeological approaches (sieving, AMS and OSL dating, artefact analyses) with pedological analyses (geochemistry, soil micromorphology), and palaeoecological analyses (palynological, botanical macro-remains, non-pollen palynomorphs; Arnoldussen \& Van der Linden 2017), the use-histories of Celtic field plots may be unravelled.

In what follows, results of the Groningen Celtic field projects are discussed across these three scales. At the macro-scale, a reappraisal of Celtic field palaeoeconomy is offered; on the meso-scale, the interrelations of houses and fields are addressed. This is followed by a discussion at the micro-scale of Celtic field dating results.

\section{PALAEOECONOMY}

On the macro-scale, the potential for obtaining meaningful results is in no small part dependent on the preservation conditions for evidence of past agricultural practice, which could provide essential data on crops sown, fallow and crop-rotation cycles, manuring strategies, etc (Klamm 1993, 50, 80). Consequently, the fact that, at the aforementioned recently excavated Someren and Herkenbosch fields, no charred botanical macroremains were recovered (Arnoldussen et al. 2014; 2016) hampers any supra-regional comparison of crops cultivated or fallow cycles. Moreover, a more methodological study into the origins and compositions of the charred macro-botanical remains in Celtic field sediments (Arnoldussen \& Smit 2017) suggests that such remains were most probably brought onto the fields as fortuitous elements of household waste (as, or in, manure) rather than reflect crops and weeds grown locally (Müller-Wille 1965, 93; Arnoldussen 2012, 43-6; Arnoldussen \& Scheele 2014, 60-1). This is best demonstrated by (a) the fact that species which require no charring as part of their preparation, preservation, or consumption (ie flax, millet) do occur solely in a burnt state, and (b) the fact that the rates of occurrence for cereals and arable weeds are discouragingly low (1.5-5 charred seeds for every 100 litres of Celtic field sediment; Arnoldussen \& Smit 2017). After sieving and screening over 1400 litres of Celtic field sediment from Westeinde-Noormansveld, and an additional 600 litres at Someren-De Hoenderboom, I am confident in stating that this low seed recovery rate is not an artefact of small-sample bias, but of past agricultural strategies in which household debris (marked by charcoal from firewood, burnt dung, and small ceramic sherds; Arnoldussen 2012; Arnoldussen \& Scheele 2014; Arnoldussen \& vander Linden 2017) was (mixed with dung and) used as a manuring agent (cf. Zimmermann 1976, 86; Behre 2000, 141; Vanmontfort et al. 2015, 142).

Whereas I have argued in the above section that it is ill advised to rely (solely) on botanical macro-remains for studying past agricultural strategies, the pollen contents of Celtic field plots and banks appear to be a far more promising record source. Despite inherent problems of mixing (by ards or hoe-type implements; cf. Brongers 1976, 51) and contamination (pollen infiltration through seepage and biological agents [eg, bees, beetles, roots] as well as supra-local influx), careful analysis of the pollen contents of field plot and bank sediments has yielded valuable information. Moreover, the durability of pollen allows interregional comparisons even of sites that show no preservation of uncharred macro-remains (the matter of geogenetic differences and field system similarities is addressed in the final section of this paper). Pollen of Triticum/ Hordeum type or, in older studies, Cerealia-pollen, were found in almost all studied Celtic fields, with Triticum dicoccum identified at Wekerom (Fig. 4, cf. Müller-Wille 1965, 94; Behre 2000, 138, 140, abb. 5). The few surviving macro-fossils suggest that - as these species were present in the settlements from which the fields were manured - barley, bread wheat, millet, and flax were also grown (Behre 2000, 138, 140, abb. 5, cf. Helbæk in Hatt 1949; Müller-Wille 1965, 94; Kroll 1987, 375). As to flax, the presence of Linum pollen in the Zeijen-Noordse Veld fields documents the cultivation of this species in Celtic field plots (Arnoldussen 2012; Arnoldussen \& vander Linden 2017). Pollen of grasses are ubiquitous in the various Celtic field plots studied, frequently accounting for half of the pollen sum (Fig. 4). This suggests that grazed grassland plots played a significant part in the Celtic field economy. At Someren-De Hoenderboom, the fluctuating and repeatedly high percentages of grasses and ling (Calluna), combined with coprophilous herbivore dung 


\section{S. Arnoldussen. USE-HISTORIES, LATER PREHISTORIC FIELD SYSTEMS IN THE NETHERLANDS}

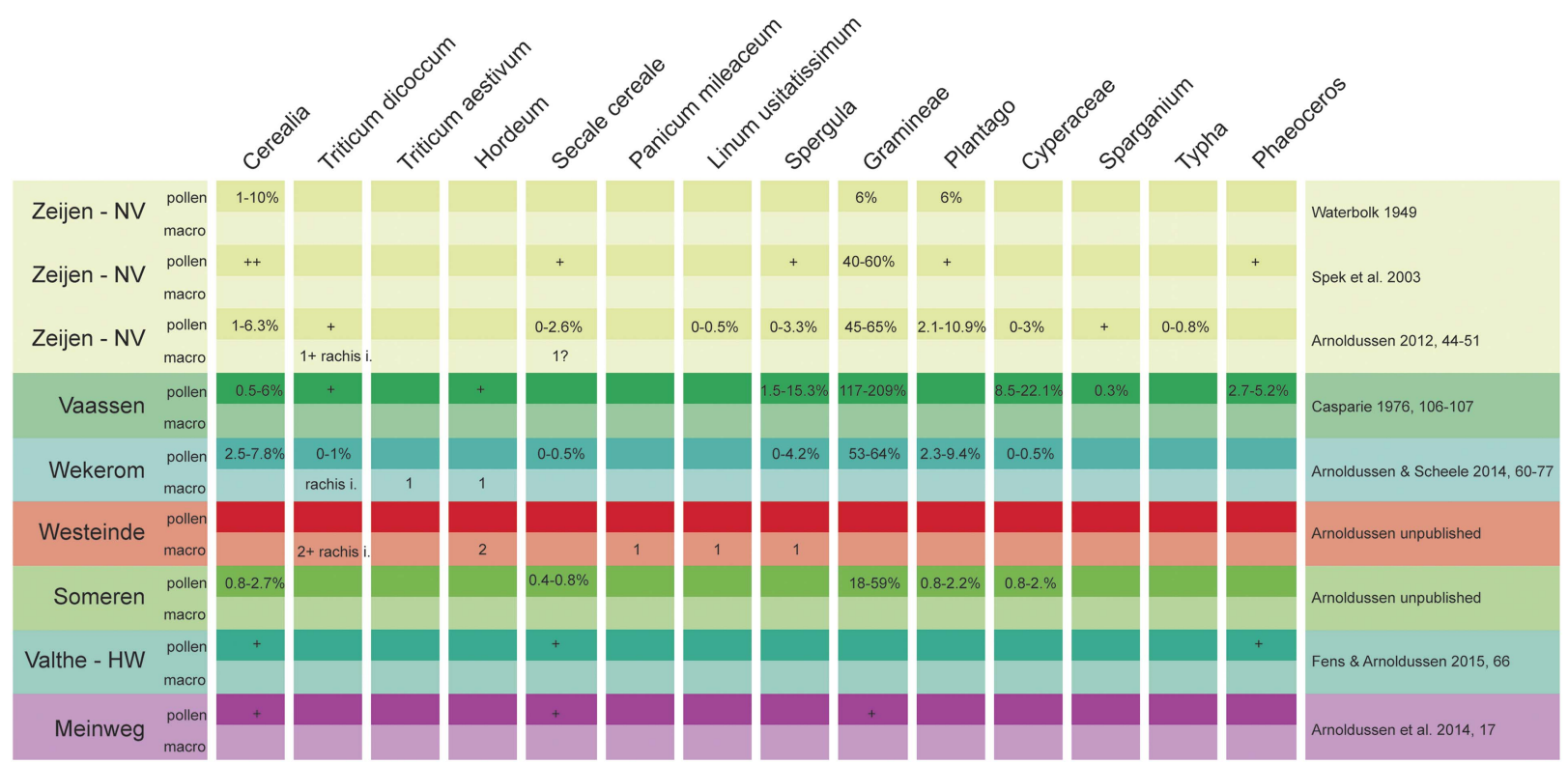

Fig. 4.

Palynological (pollen) and macrobotanical (macro-)remains of foodcrops and a selection of cultural and landscape indicators for Dutch Celtic fields. Cerealia = cereals, indet.; Triticum dicoccum = emmer wheat; Hordeum = barley; Secale cereale = rye; Panicum miliaceum = millet; Linum usitatissimum = flax/linseed; Spergula = spurrey; Gramineae = grasses;

Plantago $=$ plantain Cyperaceae $=$ sedges; Sparganium $=$ bur-reed; Typha $=$ bulrush; Phaeoceros $=$ hornworts

fungi (Sordaria-type), suggest that several plots of that Celtic field must have been used for grazing (Arnoldussen et al. 2016). However, it still remains unclear what proportion of field plots may have been used for grazing, or according to what cycles (as part of fallow regimes?) those plots were not cultivated. Moreover, an interregional comparison of plant species that may yield information on fallow durations (eg, biennials) and of nutrient conditions (eg, nitrogen and phosphate proxies, stable isotopes) is yet to be undertaken.

Despite these observations on the nature of Dutch Celtic field farming, it should be stressed that various specifics of the agricultural strategy, such as the balance of livestock rearing versus crop cultivation, crop rotation strategies and the role of fallow periods, remain poorly understood (cf. Jankuhn 1958, 203, 205; Fowler 1983, 112; Klamm 1993, 50, 80;). Possibly, the dominance of wild herbs and arable weeds over cereals may one day prompt the conclusion that fallow periods were an integral part of the agricultural strategy (Becker 1971, 97-8; Groenman-Van Waateringe 1980, 364-6; Liversage et al. 1985; Odgaard 1985; Klamm 1993, 81). Behre (2008, 155) assumes that at most $10 \%$ of the Flögeln Celtic field plots were in use simultaneously, suggesting a regime of extensive use (cf. Zimmermann 1976, 88-9; Smith 1996, 214; Spek et al. 2003; Løvschal \& Holst 2014, 8). For the Danish site of Grøntoft, Odgaard (1985, 127) argued that the nutrient status of the fields allowed tillage over longer periods with minimal, if any, fallow.

\section{HOUSE AND FIELD INTERRELATIONS}

At the meso-scale, the developmental histories of individual Celtic field complexes were investigated. This entailed a combination of re-analyses of previously excavated Celtic fields with new, targeted fieldwork. A complicating factor is that the inherently destructive nature of excavation means that it is costly in terms of 'scientific gain/loss' (as well as in financial terms) to uncover Celtic fields to the extent required to study the interrelations between habitation and agriculture. Ideally, one would topsoil-strip known Celtic fields where the banks had already been levelled by erosion and/or modern agriculture; in such locations, a broad perspective on the degree and nature of activities taking place in the fields might be obtained, without the loss of evidence involved in levelling banks and stripping fields during an excavation. At locations 

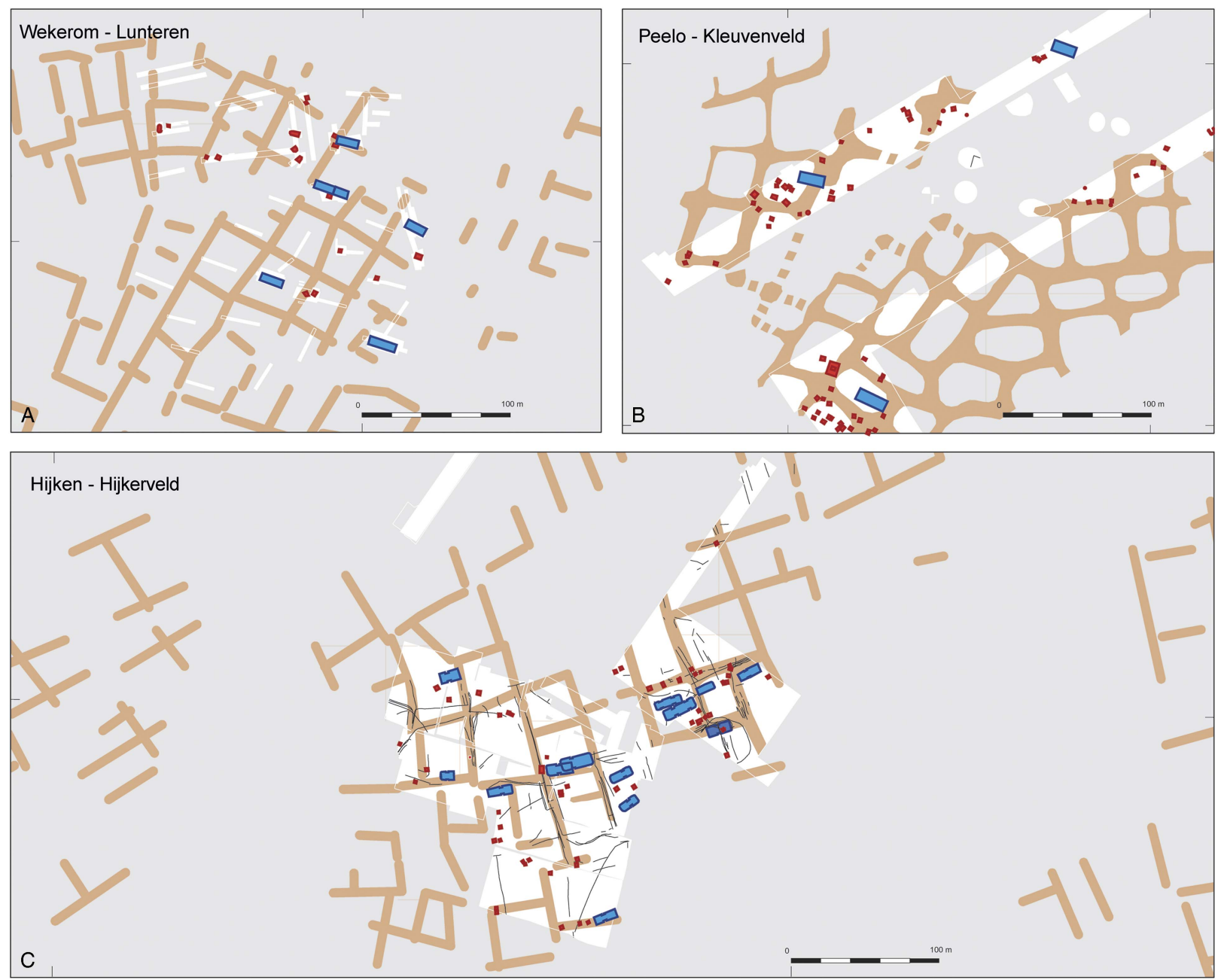

Fig. 5.

Association of Iron Age house sites (houses in blue and outbuildings in red) with Celtic field banks (brown) at three larger Celtic field excavations. Excavated areas in white. Not to the same scale. A: Wekerom-Lunteren (after Van Klaveren 1986; Arnoldussen \& Scheele 2014); B: Peelo-Kleuvenveld (after Kooi \& De Langen 1987); C: Hijken-Hijkerveld (wattlework fences as black outlines; after Harsema 1991; Arnoldussen \& De Vries 2014)

where bank or field sediments have been preserved, I would argue that excavating these in full would cause an irresponsible loss of evidence, and test-trenches are perhaps more appropriate. Fortunately, the long research history into Dutch Celtic fields provides us with an (albeit limited) dataset on previously excavated Celtic fields.

As I have dealt with the awkward interrelations between house sites and Celtic field plots in more detail elsewhere (Arnoldussen \& De Vries 2017), I shall only briefly summarise the main conclusions here. First, it seems that the habitation features uncovered in Dutch Celtic fields span the Early to Late
Iron Age period (c. 800 вС-12 вC; for the chronology see Van den Broeke et al. 2005), and the longhouses of those periods often appear to be situated (partly) on the banks (Fig. 5), in spite of popular artists' impressions (Fig. 3) that slot them neatly into field plots (cf. Bradley 1978, 272). The observations that at several excavations multiple house sites were uncovered - eg, five at Wekerom (Arnoldussen \& Scheele 2014, 15, fig. 8) and at least eight at Hijken (Arnoldussen \& De Vries 2014, 93, fig. 7) and that even at sites with a much lesser degree of investigation house sites were still found, suggest that up to $20 \%$ of field plots may have supported 


\section{S. Arnoldussen. USE-HISTORIES, LATER PREHISTORIC FIELD SYSTEMS IN THE NETHERLANDS}

habitation at some given point in time (Arnoldussen $\&$ De Vries 2017). Evidently, the time depths involved in house site (re)location are restricted compared to those of bank formation (infra), and - despite the often limited size of the excavations - the excavated sites suggest that house plans uncovered within Celtic fields appear not to reflect the Celtic fields' integral use-life. The conformity in structural details and shared orientation of these houses (cf. Fig. 5) indicate broad contemporaneity and suggest that habitation occurred only during specific parts of the Celtic field's much longer (infra) use-life.

At the sites of Vaassen and Hijken there is evidence to suggest that Celtic field banks were bounded by or succeeded wattle fencing (Vaassen: Brongers 1976, 52; Hijken: Arnoldussen \& De Vries 2014, 101, fig. 12). These two observations suggest that the initial planning of Dutch Celtic field landscapes may have relied on fences that were later substituted by banks (cf. Becker 1971, 103-4; Løvschal 2015, 261). The banks themselves contain a mixture of settlement debris (firewood charcoal, sherds, burnt dung, burnt cereals), dung (as indicated by coprophilous herbivore-dung fungi), dislocated clastic elements (possibly sods used previously as byre bedding; cf. Kroll 1987; Liversage \& Robinson 1993, 51; Bradley 1978, 272; Behre 2000, 142; 2008, 154-5), and wetland indicators (sedges, reeds, freshwater algae, remains of either wetland sods or fodder). Because of this, I have suggested (Arnoldussen 2012, 57-60; Arnoldussen \& Scheele 2014, 88-92; Arnoldussen \& vander Linden 2017) that the banks' composition mirrors that of the fields that they enclose; presumably the banks increased in height through the deposition of uprooted plants with soil attached to their roots, or by stripping the fallow fields' turf and dumping this at the field's margins (a process in which the organic waste piled high enough to make redundant the function of the initially present fencing). In the words of Løvschal (2014, 736), '... repeated use had a clear cumulative effect, leading to some parts becoming more materially stable, higher, and more visually prominent than others. Moreover, as soon as they had become established as visual banks or walls, they gained a certain degree of inertia'.

The above interpretation of gradual bank formation through recurring agricultural activities (manuring, weeding, field preparation) by which sediment accumulated into banks, implies that the banks themselves may form chronostratigraphic records of the agricultural usehistory of the plots they enclose. To test this hypothesis, detailed analytical and dating efforts on sections of individual Celtic field banks are required.

\section{DATING DUTCH CELTIC FIELDS}

The dating of Celtic fields (or their banks) is difficult. Based on pottery frequently recovered from the banks, a Late Bronze Age/Early Iron Age usage may be expected (Arnoldussen 2012, 54; Arnoldussen \& Scheele 2014, 80). Radiometric dating can refine this, but the interpretative strength of single radiocarbon dates from banks is strongly reliant on the understanding of their complex lithogenetic context and sample quality. For the radiocarbon samples obtained previously at Vaassen, their lithogenetic context was often unclear (Brongers 1976, 64, 104), albeit Early Bronze Age terminus post quem dates and Early Medieval terminus ante quem dates (ibid., 53, 104) are undisputable. The relevance of the single Middle-Late Iron Age radiocarbon date obtained for the ZeijenNoordse Veld bank (Fig. 6; Spek et al. 2003, 165) is difficult to determine, as it is unclear where the original surface was located, but the date suggests bank development after the Middle Iron Age.

To avoid the known problems of radiocarbon dating (known age of sample, risk of bioturbation), the Groningen Celtic field programme has relied on Optically Stimulated Luminescence (OSL) dating of the bank sediments proper. For the samples here discussed, at least 21 aliquots per sample (average 175 grains, $180-212 \mu \mathrm{m}$, chemically pre-treated with $\mathrm{HCl}$ $>\mathrm{H}_{2} \mathrm{O}_{2}>\mathrm{HF}>\mathrm{HCl}$ rinsing) were dated, using the Central Age Model (CAM) and a 'bootstrapping' approach (full methodology: Wallinga \& Versendaal 2013a-b; Voskuilen et al. 2016). By using this technique with several samples from individual banks at Zeijen, Wekerom, and Someren, it could be determined when bank development occurred and whether this was a one-off event or a long term trajectory. AMS dating was used additionally (at Someren) or instead (at Westeinde) to establish the use-life of the Celtic field banks at these sites.

\section{Zeijen-Noordse Veld}

Despite its long research tradition (supra), prior research at Zeijen had not yielded very precise dates for the use of the Celtic field. In 1918, Van Giffen could not identify the recovered pottery more closely than as being of 'Germanic' origin (Van Giffen 1918, 153), and for the 

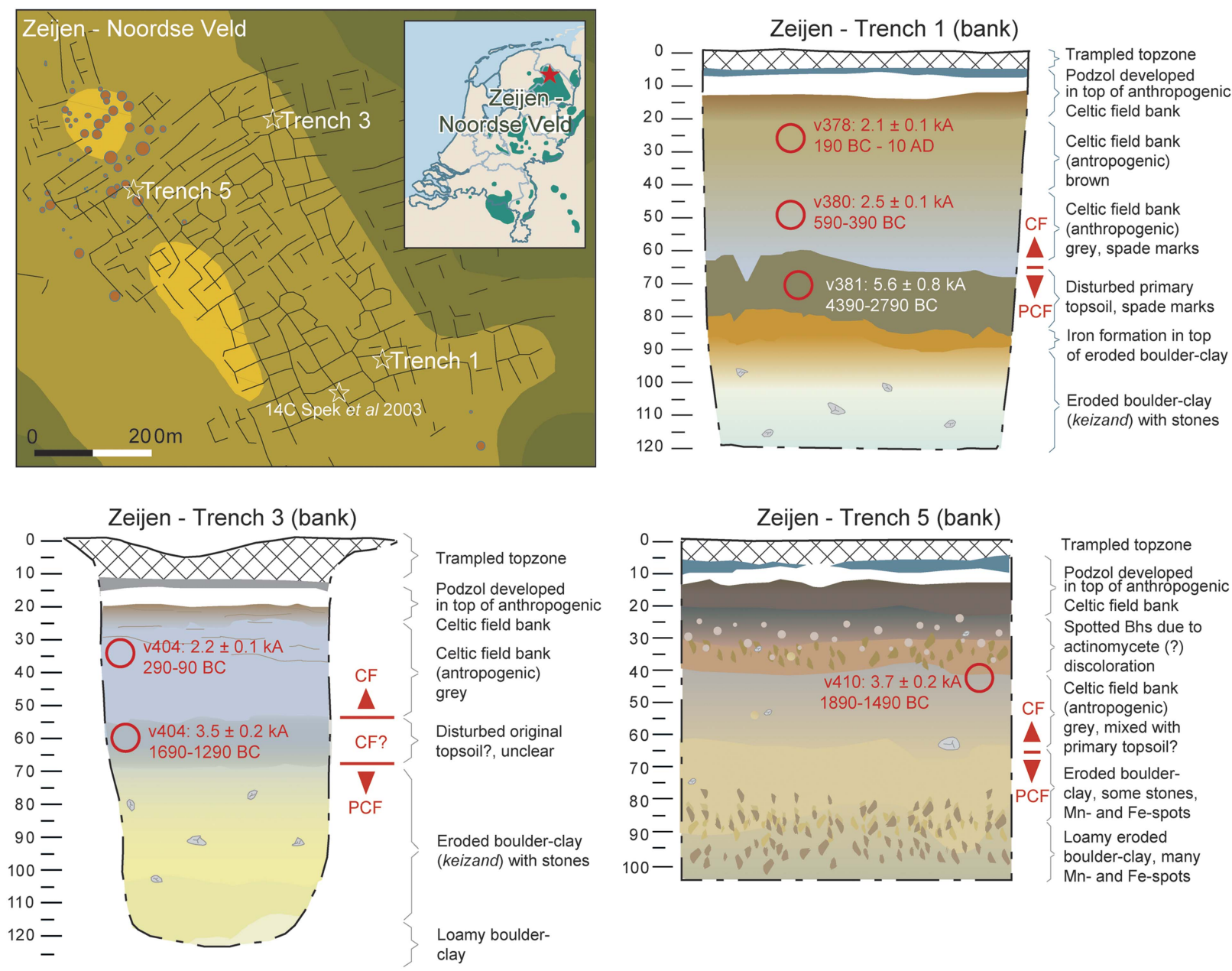

Fig. 6.

Overview and geogenetic interpretation of Celtic field banks at Zeijen-Noordse Veld (after Arnoldussen 2012; dates: Wallinga \& Versendaal 2013b). The locations of the OSL samples are indicated as red circles

Middle Iron Age pottery recovered in 1953 (Waterbolk 1977, fig. 8; Taayke 1996, 67, 72, n. 261) its stratigraphic position with regard to the banks is unclear (Arnoldussen 2012, 17). A more solid stratigraphic resource was a cinerary barrow on top of a Celtic field bank, which yielded an urn that Van Giffen dated to the final Bronze Age (Van Giffen 1949, 119, fig. 20, 137) but which since has been dated typologically to the Late Iron Age (Glasbergen 1954, 70; Brongers 1976, 26). A radiocarbon date of $384-198 \mathrm{cal} \mathrm{BC}$ (UtC-3073: $2240 \pm 40$ BP; Spek et al. 2003, 165) obtained at $55 \mathrm{~cm}$ depth from a nearby bank (Spek et al. 2003, 163, fig. 6; see Fig. 6 for location) can only provide a general terminus ad quem date, as its stratigraphic position with respect to the underlying surface is unclear; in other words, one cannot determine whether it relates to early, middle, or late bank formation.

Based on the Groningen Celtic field project excavations, the oldest agricultural phases, presumably predating bank formation, were dated to $4390 / 2790$ BC (bank 1) and 1680/1280 BC (bank 3) (Wallinga \& Versendaal 2013b, 6, tab. 2). The homogenisation of those layers, and particularly the presence of hoe- or spade marks at this level in trench 1 (Arnoldussen 2012, 28-9), indicate that agriculture was already practised before bank development took place, as the original primary soil was disturbed and incorporated into these layers (Fig. 6; cf. Van Giffen 1940, 202). A 4th millennium date for the lowermost sample from trench 1 may be related to Funnel Beaker period activity, as a Middle 


\section{S. Arnoldussen. USE-HISTORIES, LATER PREHISTORIC FIELD SYSTEMS IN THE NETHERLANDS}

Neolithic passage grave is situated at $750 \mathrm{~m}$ south-west of trench 1 (Van der Sanden 2012, 28). For trench 3, the lowermost sample suggests that homogenisation of the primary surface took place early in the Middle Bronze Age (17th-14th centuries $\mathrm{BC}$ ) - again hinting at a phase of agriculture predating bank development.

The sample from the lowermost third part of the bank sediment in trench 5 suggests that bank construction may have taken place even before the 15th century BC. A sample from a similar stratigraphic position in trench 1 indicates that for other banks an Early Iron Age terminus ante quem is probable. Younger OSL dates from higher up in the banks indicate that the vertical aggradation of the banks will have been a slow process (cf. Arnoldussen \& vander Linden 2017): the topmost samples from trenches 1 and 3 both indicate a Late Iron Age (c. 3rd/2nd century $\mathrm{BC}-\mathrm{AD} 1)$ usage. The facts that (a) the topmost OSL dates were taken at locations $25-30 \mathrm{~cm}$ down from the bank's top (to avoid contamination caused by bioturbation), and (b) the present day bank is likely to be lower than it was in prehistory as a result of subsequent wind erosion, trampling, and possibly Medieval sod cutting, suggest that bank formation at Zeijen continued well into the Roman Era.

\section{Someren-De Hoenderboom}

As for the site of Someren-De Hoenderboom (Fig. 7), no prior research into the age and use-history of this Celtic field had been undertaken; it had previously been (mis-?)identified as an urnfield (Hermans 1865, 89; Kortlang \& Van Ginkel 2016, 89), and LiDAR identification of the banks did not take place until 2011 (Arnoldussen 2013, 62). Fieldwalking campaigns in 1988 and 2001 yielded some Late Bronze Age and Early Iron Age potsherds (Van der Gaauw 1989, cat. no. 6).

Between 2012 and 2014, a series of targeted excavations of the Celtic field banks and fields took place. For a $55 \mathrm{~cm}$ high bank (trench 7), a strategy of OSL dating combined with AMS dating of the section was undertaken. The two lowermost AMS dates (Fig. 7, trench 7 ) indicate that (a) the primary underlying soil had been decapitated by the later Celtic field tillage, and (b) residual charcoal indicated human activity in the 5th and 4th millennia BC. The three dates obtained from the base of the anthropogenic Celtic field bank upwards suggest human activity in the 18th-15th centuries BC. This tallies well with the oldest OSL dates from Zeijen (trenches $4 \& 5$; Fig. 6), but it would be too simple to postulate that these banks also evolved from the start of the Middle Bronze Age. The fact that the lowermost OSL date of trench 7 dates to 1065-325 BC, while being stratigraphically at the same height as the topmost two Middle Bronze Age AMS dates, indicates that in the process of bank aggradation Middle Bronze Age charcoal was still incorporated higher into the banks. Ploughmarks oriented obliquely to the field system, discovered at various depths within the banks (Arnoldussen et al. 2016), could suggest ploughing episodes that occurred after prolonged fallow periods and indicate the use of a heavy ard for breaking the sod (Groenman-Van Waateringe 1980, 363; McIntosh 2009, 120). This infrequent but deeper type of ploughing presumably facilitated the upward displacement of older charcoal. Probably an initial Middle Bronze Age phase of cultivation (which did not necessarily involve banks) was at the Middle to Late Bronze Age transition followed by a system that did involve net sediment input to the banks - thus causing vertical bank aggradation. Such a developmental trajectory may have applied to Zeijen Bank 3 as well, where the lowermost part of the bank may also represent a homogenised mixing of the primary soil horizons due to Bronze Age agriculture (Fig. 6).

Apart from an obvious recent intrusion (Someren v219; AMS AD 1993/1994), the topmost AMS dates of trench 7 at Someren may indicate bank formation well into the Iron Age. The topmost OSL date for that bank (at $25 \mathrm{~cm}$ depth) even spans the period $165 \mathrm{BC}-\mathrm{AD} 165$. This means that bank formation may have continued into the first two centuries of the Roman era. The fragment of a handle of a Roman jug (possibly of Stuart 130 type; Stuart 1977, 54) datable to the 1st or 2nd century AD was recovered at a depth of $35 \mathrm{~cm}$ and indeed provides confirmation of such longstanding bank formation. The majority of the pottery recovered in sieving the sediment from several Celtic field banks at Someren, however, dated from the Late Bronze Age and Early Iron Age (c. 1000-500 BC).

As the dates obtained for the Someren Celtic field bank present a chronostratigraphic accumulative record due to a net input of sediment (through a combination of uprooted field weeds [cf. Jankuhn 1958, 181], manure, and compost; Arnoldussen \& vander Linden 2017; Fokkens 1998, 121), a second series of AMS dates was undertaken for the adjacent field plot (trench 12), where stratification of ard-marks also proved net sediment input. In the field plot, 

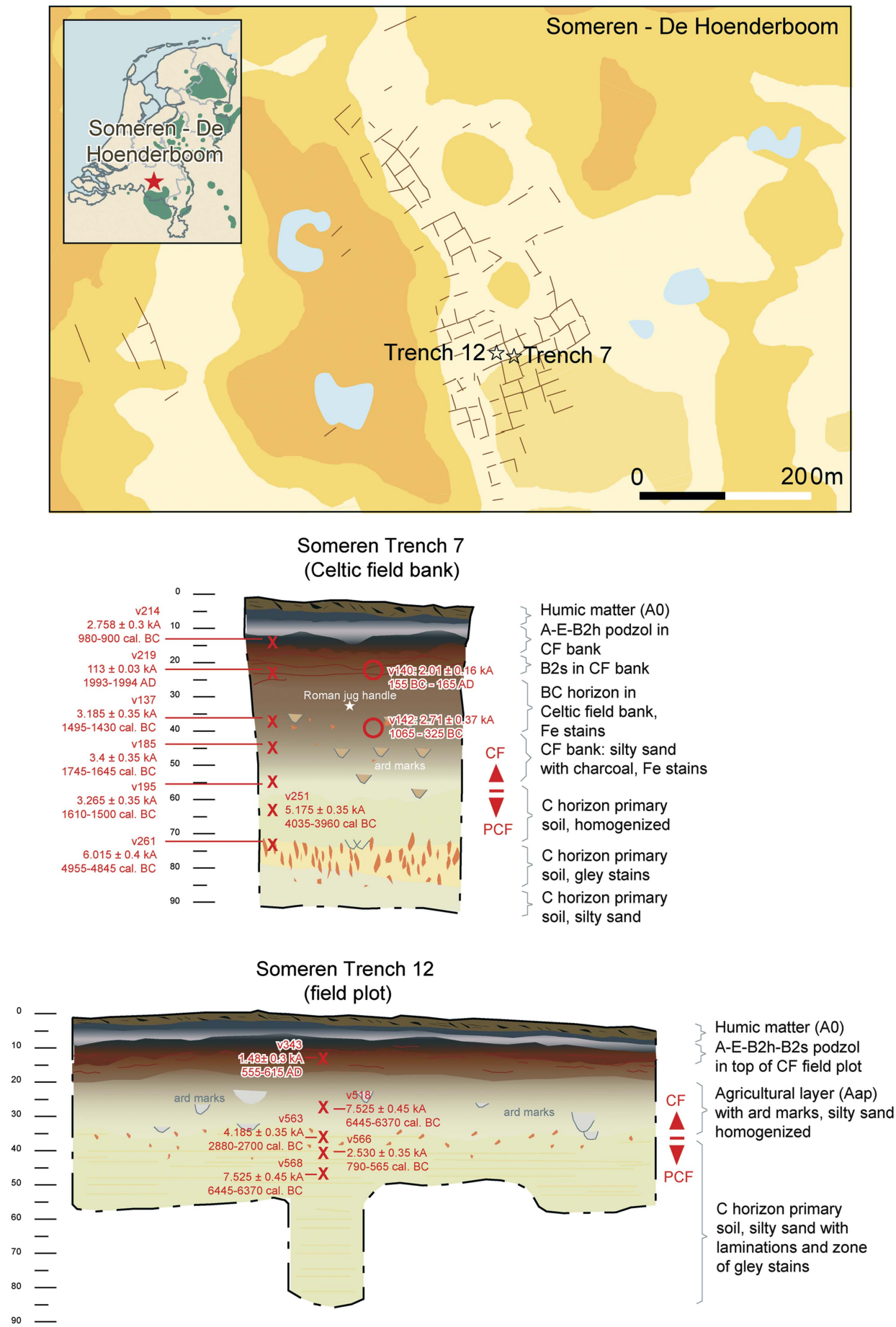

Fig. 7.

Overview and geogenetic interpretation of Celtic field banks at Someren-De Hoenderboom. The locations of the OSL samples are indicated as red circles; those of AMS samples are marked with red crosses 


\section{S. Arnoldussen. USE-HISTORIES, LATER PREHISTORIC FIELD SYSTEMS IN THE NETHERLANDS}

however, no chronostratigraphy was preserved (owing to more frequent ploughing?). The scattered dates suggest human activity around the 7th and 3rd millennia $\mathrm{BC}$ and during the Early Medieval period, with only a single date $(790-565 \mathrm{cal}$ BC; GrA-64734: Table 1) that may actually pertain to the Celtic field's use-phase proper (Fig. 7, trench 12).

\section{Wekerom-Lunteren}

The presence of a field system from later prehistory at Wekerom had been known since the 19th century, when the curator of the Leiden National Museum of Antiquities, Janssen $(1848,11)$, had parts of it mapped (Brongers 1976, 123, fig. 4). In 1939-1941 another curator of the same museum, Frans C. Bursch, dug trial trenches in several of the fields in the northwesternmost part of the Wekerom Celtic field (Fig. 5, A; Arnoldussen \& Scheele 2014, 14, fig. 7). Unfortunately, no stratigraphic relation between houses and banks was recorded, and for much of the recovered pottery assemblage (mostly Middle Iron Age; ibid., 18), it is unclear to what house or trench feature it belonged.

In 2012, various field plots and banks of the Wekerom-Lunteren Celtic field were excavated as part of the Groningen Celtic field programme (Arnoldussen \& Scheele 2014). Here, too, a campaign of OSL dating was undertaken to establish a chronology for bank construction. The lowermost OSL dates for the banks in trenches 1 and 10/13 both spanned the period of 1290-890 BC (Fig. 8; Wallinga \& Versendaal 2013a, $6)$, indicating bank construction from the 13th-10th centuries BC onwards. At both banks, the OSL sample situated $c .10-15 \mathrm{~cm}$ higher in the bank yielded a date of 990-790 BC (ibid.; Arnoldussen \& Scheele 2014, 66), which hints at very slow accumulation rates for the banks (cf. Klamm 1993, 44; Zimmermann 1995, 293; Gerritsen 2003, 175, 177). This is confirmed by the topmost OSL date of trench 10/13, which was again situated $c .15 \mathrm{~cm}$ higher and was dated to the 5 th or 4th century BC. As a very crude 'rule of thumb' as it assumes growth to be continuous and linear - the Wekerom OSL dates suggest an accumulation rate in the order of 30 years per $\mathrm{cm}$ for these Celtic field banks (Arnoldussen \& Scheele 2014, 66; 92). Above the topmost sample in trench $10 / 13$ still c. $25 \mathrm{~cm}$ of bank remained (which was avoided for fear of contamination), which again suggests that - as at Someren - bank aggradation may have continued into the Roman period.

\section{Westeinde-Noormansveld}

The Celtic field of Westeinde-Noormansveld - like that of Someren - was largely unknown prior to the availability of LiDAR altimetry data in 2010. In hindsight, the banks around a single field plot had already been mapped in 1999, when restoration of the barrow group known locally as 'Noormansveld/ Boerdennen' was undertaken (Fig. 9; Van Zeist 1955; Datema 2003). It was only through the availability of LiDAR imagery that the full extent (over 34 ha) of the Westeinde Celtic field became clear (Fig. 9).

Between 2014 and 2017, various barrows, banks, and field plots of the Westeinde Celtic field were investigated as part of the Groningen University Archaeology Field School. Particular attention was given to the vicinity of Tumulus 41 , which appeared to be connected to a Celtic field bank. The possible stratigraphic relation between the barrow and the field embankment was investigated by means of a series of small trenches (Fig. 9, trenches 12-14). Trench 12 was a narrow, deep cut that utilised a modern looting pit dug into the barrow, so as not to disturb the mound even more. The sections showed that Tumulus 41 had been constructed on top of the Celtic field bank. An AMS-dated fragment of charcoal from the barrow places its construction in or after the 4th or 3rd century $\mathrm{BC}-\mathrm{a}$ scenario not unlike that of the Late Iron Age cinerary barrow built on top of the bank at Zeijen (supra; Van Giffen 1949, 119, fig. 20). From the Celtic field bank underlying Tumulus 41, two radiocarbon dates were obtained that suggest bank development in the 8th-6th centuries BC. A charred fragment from the charcoal-rich deposit at the base of the Celtic field bank in trench 6 was dated to the $c$. 5th century вС (Fig. 9), hinting at a somewhat later start of bank construction here. As this sample was taken from an area that also showed some post-holes, contamination from more recent activities cannot be ruled out (and, given that a sample from the same layer in trench 12 was dated to 755-540 cal вс (GrA-62653; Table 1), this may indeed be the most likely scenario).

\section{Conclusion of the dating programme}

As samples from the lowermost and uppermost parts of the banks are less suitable for OSL dating because of the risk of contamination with older (glacial sediments underlying the banks) or younger (modern surface) sediments, the newly obtained ages can only roughly frame the main period of use. We should also 
TABLE 1: ALL DATES (INCLUDING FIELD-PLOT LOCATIONS \& OUTLIERS)

\begin{tabular}{|c|c|c|c|c|c|c|c|c|}
\hline $\mathrm{Nr}$ & Site & Context dated & Method & Description & Labcode & $B P$ & $B C / A D$ & References \\
\hline v381 & Zeijen & Palaeosol & OSL & Disturbed level under bank, trench 1 & NCL-7212014 & $5.6 \pm 0.8 \mathrm{kA}$ & $3390-2790$ вс & 1 \\
\hline v380 & Zeijen & Bank & OSL & Lower third bank, trench 1 & NCL-7212013 & $2.5 \pm 0.1 \mathrm{kA}$ & $590-390$ вс & 1 \\
\hline v378 & Zeijen & Bank & OSL & Upper third bank, trench 1 & NCL-7212012 & $2.1 \pm 0.1 \mathrm{kA}$ & 190 BC-AD 10 & 1 \\
\hline v404 & Zeijen & Bank/ palaeosol? & OSL & Base of bank (\& paleosol?), trench 3 & NCL-7212017 & $3.5 \pm 0.2 \mathrm{kA}$ & $1690-1290$ вС & 1 \\
\hline v405 & Zeijen & Bank & OSL & Lower third bank, trench 3 & NCL-7212016 & $2.2 \pm 0.1 \mathrm{kA}$ & $290-90$ вс & 1 \\
\hline v410 & Zeijen & Bank & OSL & Lower third of bank, trench 5 & NCL-7212019 & $3.7 \pm 0.2 \mathrm{kA}$ & $1890-1490$ вс & 1 \\
\hline UtC-3073 & Zeijen & Bank & AMS & Terminus ad quem? Charcoal mid-bank & UtC-3073 & $2240 \pm 40$ & $384-198$ вс & 2 \\
\hline v140 & Someren & Bank & OSL & Bank, upper third, trench 7 & NCL-71315230 & $2010 \pm 160$ & 155 вС -AD 165 & 3 \\
\hline v142 & Someren & Bank & OSL & Bank, lower third, trench 7 & NCL-71315231 & $2710 \pm 370$ & $1065-325$ вс & 3 \\
\hline v214 & Someren & Bank & AMS & Bank, trench $7,15-20 \mathrm{~cm}, \mathrm{v} 214$ & GrA-64741 & $2785 \pm 30$ & $980-900$ вс & 4 \\
\hline v219 & Someren & Bank & AMS & Bank, trench $7,20-25 \mathrm{~cm}, \mathrm{v} 219$ & GrA-64743 & $113 \pm 0.4$ & AD 1993-1994 & 4 \\
\hline v137 & Someren & Bank & AMS & Bank, trench $7,35-40 \mathrm{~cm}, \mathrm{v} 137$ & GrA-64897 & $3185 \pm 35$ & $1495-1430$ вС & 4 \\
\hline v185 & Someren & Bank & AMS & Bank, trench $7,40-45 \mathrm{~cm}, \mathrm{v} 185$ & GrA-64899 & $3400 \pm 35$ & $1745-1645$ вС & 4 \\
\hline v195 & Someren & Bank & AMS & Bank, trench 7, 50-55 cm, v195 & GrA-64842 & $3265 \pm 35$ & $1610-1500$ вС & 4 \\
\hline v251 & Someren & Bank & AMS & Bank, trench 7, 60-65 cm, v251 & GrA-64742 & $5175 \pm 35$ & $4035-3960$ вС & 4 \\
\hline v261 & Someren & Bank & AMS & Bank, trench $7,70-75 \mathrm{~cm}, \mathrm{v} 261$ & GrA-64841 & $6015 \pm 40$ & $4955-4845$ вС & 4 \\
\hline v343 & Someren & Field & AMS & Field, trench $12,10-15 \mathrm{~cm}$ & GrA-64738 & $1480 \pm 30$ & AD $555-615$ & 4 \\
\hline v518 & Someren & Field & AMS & Field, trench $12,25-30 \mathrm{~cm}$ & GrA-64736 & $7525 \pm 45$ & $6445-6370$ вс & 4 \\
\hline v563 & Someren & Field & AMS & Field, trench $12,35-40 \mathrm{~cm}$ & GrA-64735 & $4185 \pm 35$ & $2880-2700$ вС & 4 \\
\hline v566 & Someren & Field & AMS & Field, trench $12,40-45 \mathrm{~cm}$ & GrA-64734 & $2530 \pm 35$ & $790-565$ вс & 4 \\
\hline v568 & Someren & Field & AMS & Field, trench $12,45-50 \mathrm{~cm}$ & GrA-64733 & $6905 \pm 40$ & $5835-5735$ вс & 4 \\
\hline v345 & Wekerom & Bank & OSL & Lower flank bank, disturbed? & NCL-7312027 & $2.4 \pm 0.6 \mathrm{kA}$ & 990 BC-AD 210 & 5,6 \\
\hline v305 & Wekerom & Bank & OSL & Lower third of bank, trench $13 / 10$ & NCL-7312024 & $2.4 \pm 0.1 \mathrm{kA}$ & $490-290$ вс & 5,6 \\
\hline v306 & Wekerom & Bank & OSL & Middle third of bank, trench $13 / 10$ & NCL-7312026 & $2.9 \pm 0.1 \mathrm{kA}$ & $990-790$ вс & 5,6 \\
\hline v307 & Wekerom & Bank & OSL & Lower third of bank, trench $13 / 10$ & NCL-7312025 & $3.1 \pm 0.2 \mathrm{kA}$ & $1290-890$ вС & 5,6 \\
\hline v97 & Wekerom & Bank & OSL & Middle third of bank, trench 1 & NCL-7312022 & $2.9 \pm 0.1 \mathrm{kA}$ & $990-790$ вс & 5,6 \\
\hline v98 & Wekerom & Bank & OSL & Lower third of bank, trench 1 & NCL-7312023 & $3.1 \pm 0.2 \mathrm{kA}$ & $1290-890$ вС & 5,6 \\
\hline v241 & Westeinde & Bank & AMS & Charcoal layer at base of bank, trench 12 & GrA-62653 & $2470 \pm 30$ & $755-540$ вс & 4 \\
\hline v302 & Westeinde & Bank & AMS & Charcoal layer at base of bank, trench 6 & GrA-62656 & $2350 \pm 30$ & $470-385$ вс & 4 \\
\hline v300 & Westeinde & Bank & AMS & Charcoal mid bank, trench 12 & GrA-62655 & $2455 \pm 30$ & $750-580$ вс & 4 \\
\hline v298 & Westeinde & Barrow on bank & AMS & Charcoal from barrow sods, trench 12 & GrA-62657 & $2205 \pm 30$ & $360-205$ вс & 4 \\
\hline
\end{tabular}

References: (1) Wallinga \& Versendaal 2013a, 6; (2) Spek et al. 2003, 165; (3) Voskuilen et al. 2016, 12; (4) this publication; (5) Wallinga \& Versendaal 2013b, 6; (6) Arnoldussen \& Scheele 2014, 66; (6) Arnoldussen not yet published 


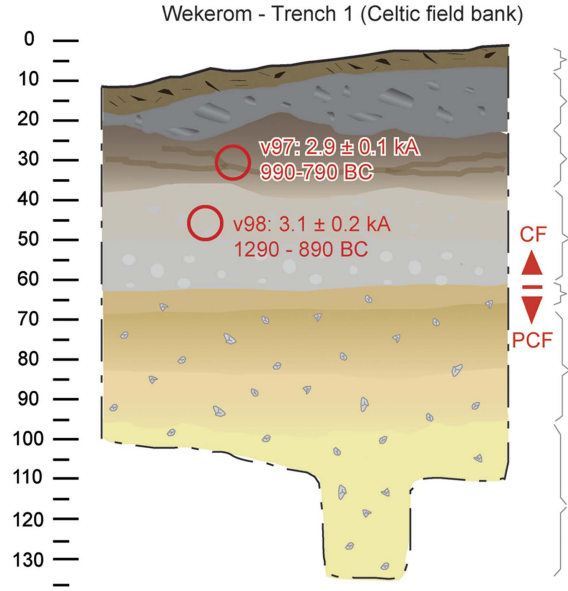

Humic matter (A0)
Disturbed A-/E-
horizons of podzol
B2h/B2s illuvial
horizon in anthro-
pogenic layer
Celtic field bank
(anthropogenic)
grey (top brownish)
Remnant of primary
E horizon?
Glacially reworked
fluvial sediments
(coarse sand, pebbles)
BC horizon primary soil
Glacially reworked
fluvial sediments
(loamy coarse sand,
pebbles)
C horizon of primary soil

Wekerom - Trench 16 (low flank of Celtic field bank)
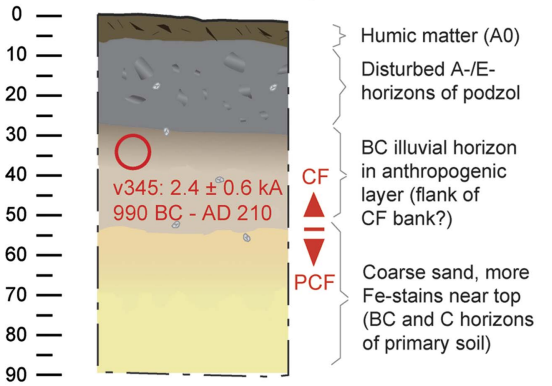
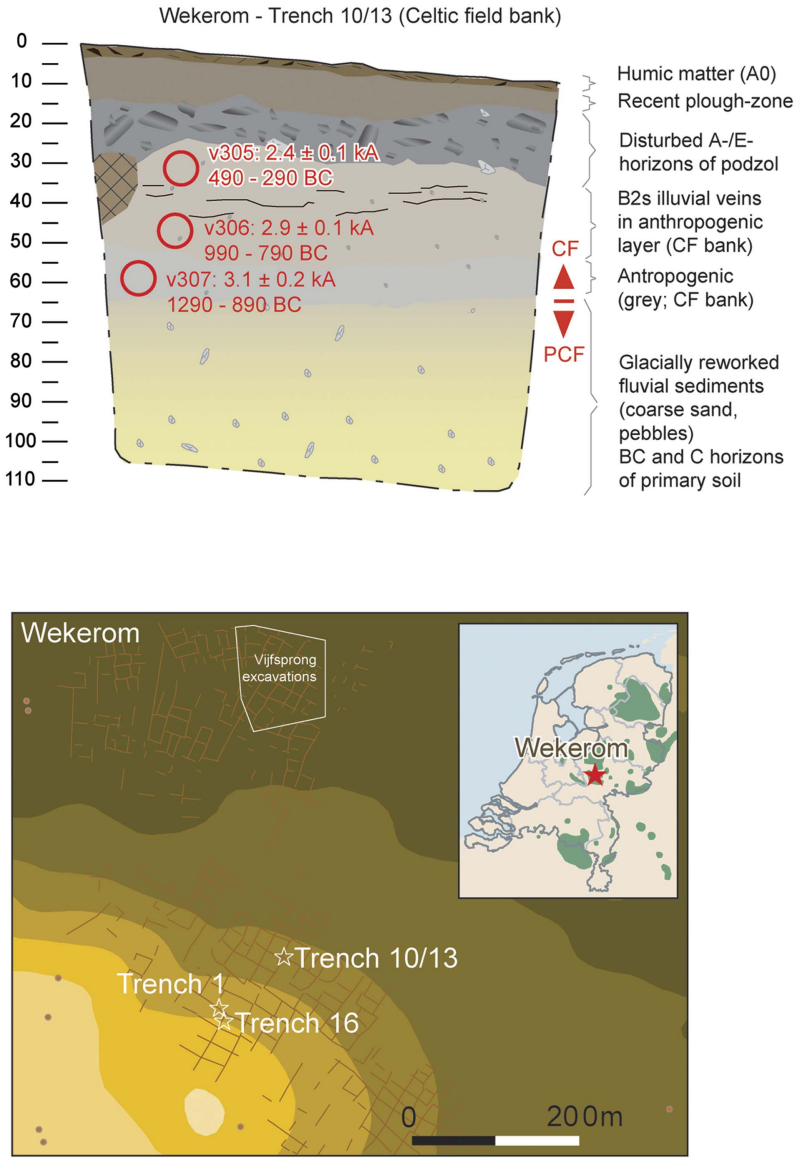

Fig. 8 .

Overview and geogenetic interpretation of Celtic field banks at Wekerom (after Arnoldussen \& Scheele 2014). The locations of the OSL samples are indicated as red circles

allow for even longer use to be reflected in the undated lower and topmost parts of the banks. Nevertheless, bank development seems to have been taking place by around the 13th-10th centuries $\mathrm{BC}$, at the close of the Dutch Middle Bronze Age-B (1500-1000 cal BC). Only the radiocarbon date for the charcoal layer at Westeinde trench 6 hints at later (5th century $\mathrm{BC}$ ) initial bank development, but potential contamination from nearby features poses an interpretative risk there. Judging by the OSL samples, but finding confirmation in the AMS dates, it appears that bank formation was an ongoing process throughout the Late Bronze Age (1000-800 cal BC) and Iron Age (800-12 cal BC).

Also, it is important to stress that in all the banks dated by OSL a distinct chronostratigraphy was observed: invariably the oldest samples within a given bank were lowermost in position, with progressively younger dates obtained for samples higher up in the banks (Someren v219 with a date of AD 1993/1994 being an obvious recent contamination; Fig. $10 \&$ Table 1). This indicates a gradual, but also tremendously long term genesis of the Celtic field banks this tallies well with low intensity sediment displacement and also with recurrent agricultural activities such as the clearing and weeding of fields, as postulated above on the basis of the contents of the banks. As regards the end of Celtic field farming, the OSL dates of Zeijen, Wekerom, and Someren all suggest continued bank aggradation into the Roman era (Fig. 10). The topmost OSL date from Someren trench 7 and the Roman jug handle suggest that the processes contributing to bank building continued there into the 2nd century AD. However, not all banks continued to grow: at Zeijen and Westeinde, there is clear evidence that in the Late Iron Age, barrows were designedly constructed on top of some Celtic field banks, whereas 

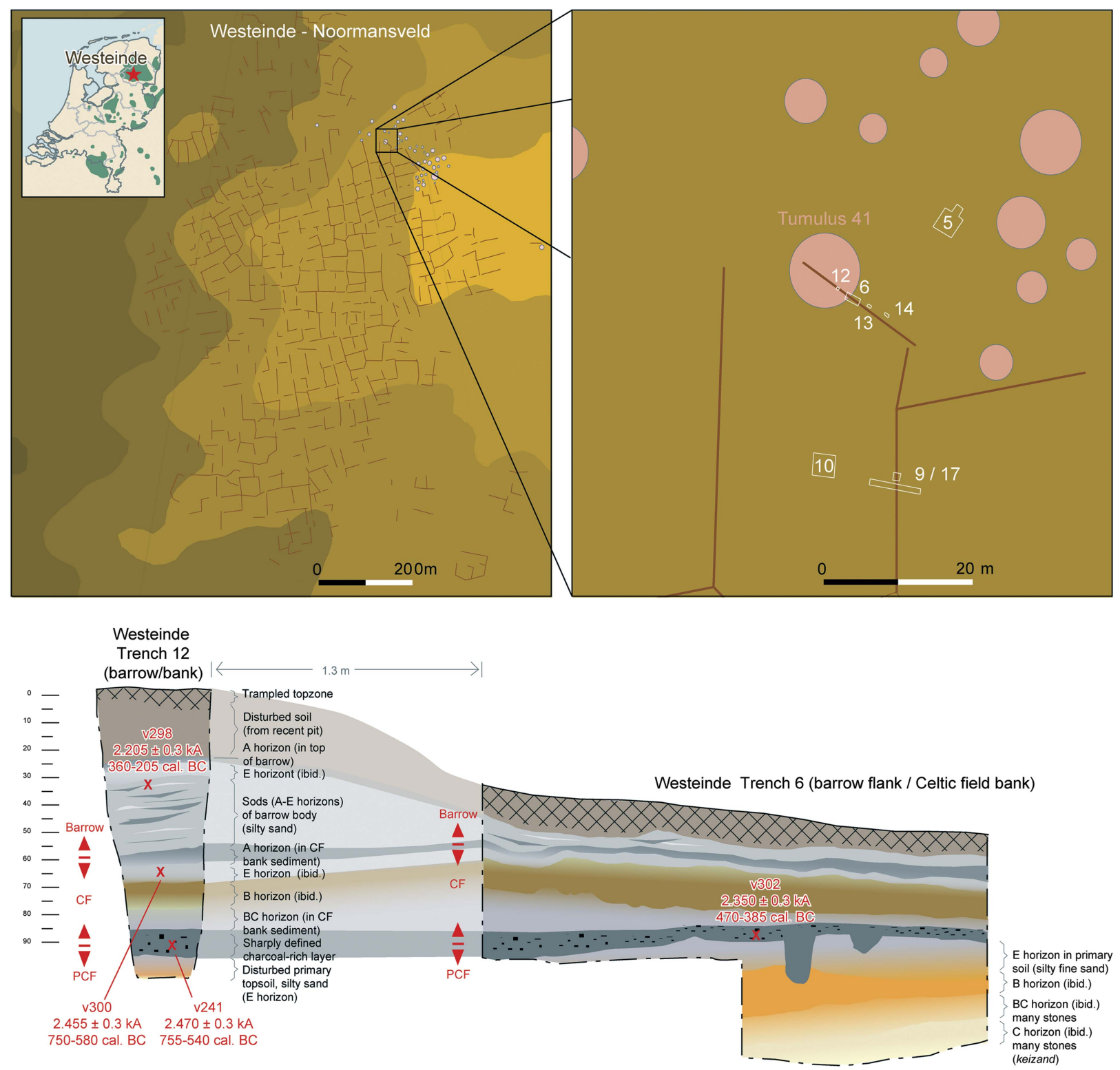

Fig. 9.

Overview and geogenetic interpretation of Celtic field banks and overlying barrow (Tumulus 41) at WesteindeNoormansveld. The positions of the AMS samples are marked by red crosses

other banks at those sites presumably retained their (agricultural) function.

\section{IMPLICATIONS: THE NETHERLANDS' MOST STABLE AGRICULTURAL LANDSCAPE}

The chronostratigraphies preserved in the Dutch Celtic field banks testify to an agricultural sustainability of use of unprecedented time-depth. For Wekerom and Zeijen, the relations between bank aggradation and documented time-depths indicate that this system was in place for at least 400-600 years (Arnoldussen \& Scheele 2014, 92), but a use-life of several centuries more is not at all improbable (considering the evidence for continued bank development above the highest dated samples). No other agricultural system or landscape from the Netherlands is 


\section{S. Arnoldussen. USE-HISTORIES, LATER PREHISTORIC FIELD SYSTEMS IN THE NETHERLANDS}

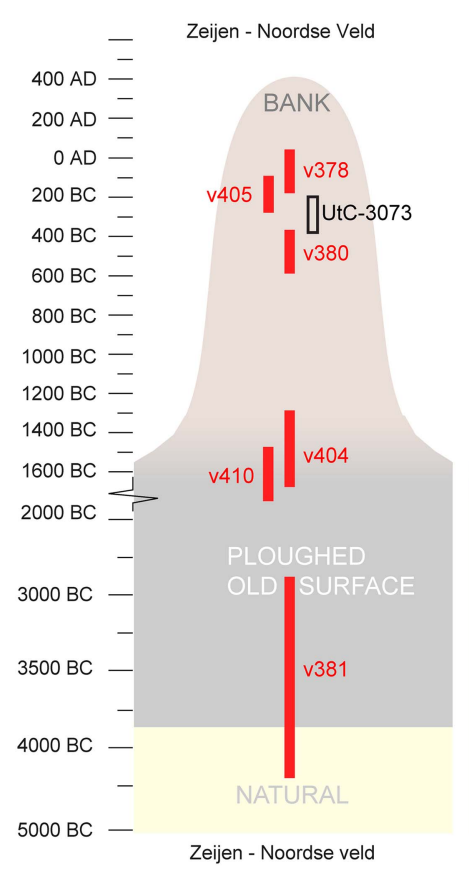

Zeijen - Noordse veld

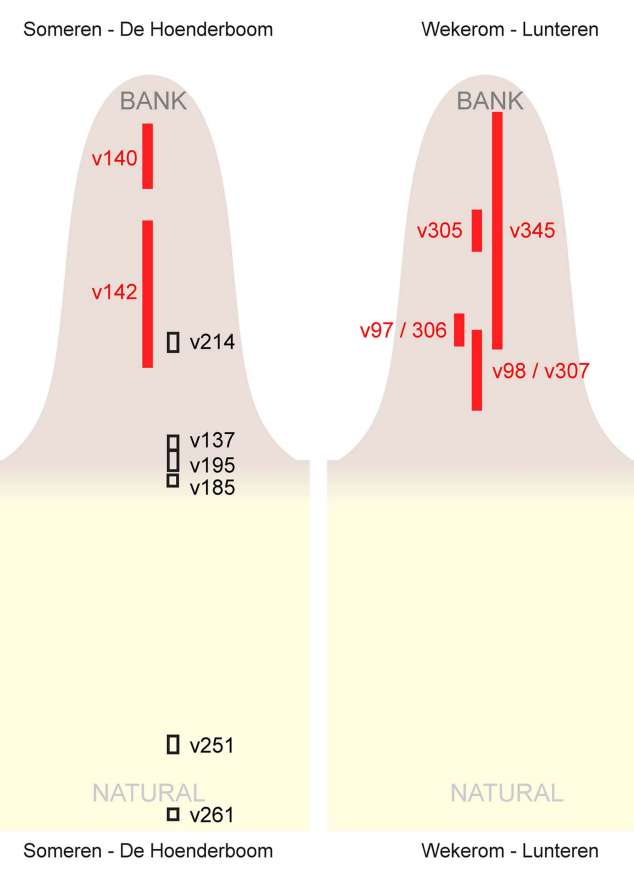

Fig. 10.

Dates from banks in four Celtic fields, by site and stratigraphic context (omitting outlier Someren v219); note the discontinuous temporal y-axis. See Table 1 known that shows such a traditionality and sustainability across the better part of a millennium. That said, this long term traditionality of form may mask a multitude of shifts and changes in the underlying agricultural regimes, which as yet have remained invisible because of the few datasets and dates available (cf. Fig. 4).

In this paper, the inception of Celtic field development has been dated several centuries earlier (ie 13th10th centuries BC) than had been traditionally assumed (eg, Harsema 2005, 543; Kooistra \& Maas 2008, 2319). Whereas the rise of prehistoric field systems in the British Isles is frequently dated to the Middle Bronze Age (Klamm 1993, 82; Bewley 2003, 82; Yates 2007, 22, 27; Wickstead 2007, 44; Sharples 2010, 36-41; Ten Harkel et al. 2017, 419), such an early start had not yet been argued for the continental field systems with earthen banks. By the Late Bronze Age, most of the field systems in southern England fell into disuse, with no evidence for new examples in Iron Age Wessex (Sharples 2010, 43). This may mean that, both in terms of an early start and of longevity (eg, the Dartmoor field systems may very well have functioned for six or seven centuries; Bewley 2003, 82, cf. Johnston 2005, 16; 2013; Fyfe et al. 2008), the Dutch raatakkers do have equivalents across the Channel, albeit that the Dutch counterparts demonstrably continued in use in both the Iron Age and Roman period.

Such an early dating of the Dutch Celtic fields may resolve a previously salient discrepancy in Dutch grand narratives of prehistoric (agri)cultural landscape development: the assumed (Late Bronze Age to) Iron Age date for the Dutch raatakkers implied that a chronological gap existed between the parcelled landscapes of the Dutch Middle Bronze Age-B (c. 1500-1000 cal BC) and those of the Iron Age (800-12 cal BC). The scale and spatial syntax of Dutch (agri)cultural landscape compartmentalisation documented in wetlands as ditches (eg, Lohof \& Roessingh 2014) or fences (eg, Arnoldussen 2008, 421-3) during the Middle Bronze Age-B were supposedly lost or rendered archaeologically invisible around the Late Bronze Age (c. 1000-800 cal BC), only to re-appear in new landscapes (upland settings) during the Iron Age with a similar spatial grammar of linearity and perpendicularity. The present reading of the data instead suggests that Dutch Celtic fields may, in their (a) devotion to compartmentalisation, (b) spatial grammar of linearity and perpendicularity, and (c) extensive spatial scale, be legitimate heirs or successors to a final Middle Bronze Age system of agricultural landscape layout. 
The centuries-long use-life of Dutch Celtic fields propounded in this paper was inferred primarily from the long continuation of an agricultural strategy in which soil from the fields ended up in the banks. This must therefore have been a process vital and inherent to the agricultural regime in question. Dumping of uprooted weeds, or processes by which topsoil from the fields was mixed on the banks with a refusemanure mix derived from the settlement sites (cf. Bradley 1978, 267; Kroll 1987, 113) are both strong candidates. Regardless of which, or what combination, of these processes was the main stable force, the stability and traditionality of bank formation should not be used as an argument for a wholly static and unchanging agricultural regime on the time-scale of centuries. At present, however, the dataset is still too sparse in terms of vertical (ie diachronic) and horizontal (ie synchronous differences in use between field plots) distribution, as well as in absolute numbers (ie numbers of Celtic fields studied) to allow much extrapolation of the data on crops grown, fallow cycles, or tillage and manuring strategies. What is important, however, is the notion put forward here that the banks around field plots provide chronostratigraphic repositories able to answer such questions in the future through more targeted fieldwork.

Also, the presented data suggests that over the prolonged use-life of Dutch raatakkers, the ways in which communities of raatakker users perceived these landscapes have differed. House sites from the earlier (13th-10th centuries cal BC) phases of Celtic field use are lacking, leaving us with a tantalizing discrepancy between the early OSL dates obtained for the start of the Celtic field regime (final Middle Bronze Age-B to Late Bronze Age) and the recovered ceramics (Late Bronze Age/Early Iron Age) on the one hand, and the uncovered house sites within them (solely Iron Age) on the other. If the layout of the Celtic field system was indeed written onto the landscape (with fencing?) before the Iron Age, where were the house sites of those periods situated (cf. Ten Harkel et al. 2017, 420)? One could argue that it is mere chance that none of these has, as yet, been identified (given the few sites investigated and small areas uncovered in such excavations; but see Fig. 5); however, more probably, final Middle Bronze Age-B to Late Bronze Age perceptions of ideal settlement locations with regard to the fields differed from those of later Iron Age communities. The scarcity of pottery from the final Middle Bronze Age and early Late Bronze Age may be explained if the tradition of adding settlement debris to the manuring mix of dung and possibly sods reflects a practice adopted only later on, from the Late Bronze Age onwards (cf. Fokkens 1998, 120).

Similarly, the fact that Middle and Late Iron Age house sites frequently are found overlapping Celtic field banks signals yet another shift in perception (cf. Becker 1971, 98, 101, fig. 21): in those periods, living amidst or even on top of - Celtic field banks was considered unproblematic, and possibly even desirable. It is striking that at this time disused urnfields were also considered proper settlement sites (Arnoldussen \& Albers 2015), which indicates that around the Middle-Late Iron Age transition shifted perceptions of suitable settlement locations were substantial and pervasive. The fact that in the Late Iron Age some banks were capped by barrows (eg, at Zeijen and Westeinde, cf. Bradley 1978, 267) again signals a fluidity of perception of these initially primarily agricultural areas. Evidently, the long standing bank formation does not belie the Celtic field regime's dynamics at smaller social, spatial, and temporal scales (cf. Becker 1971, 104). There will have been considerable variation in 'what crops were grown where' through the years, and Celtic field users (households or larger social clusters, cf. Bewley 2003, 84; Gerritsen 2003, 179; Johnston 2005, 13; Wickstead 2007, 46-7) may have made individual decisions on the use of particular plots (eg, crops, fallow, grassland) at different points in time. Similarly, chosen durations of fallow cycles or the addition of new areas to existing Celtic fields both provided additional variability to the temporal (agricultural cycles) and spatial (extension) dimensions of Celtic fields in late prehistory.

Considering this high potential for stochastic variability on the spatio-temporal scale of the Celtic field user communities (supra), their morphological uniformity across the various geogenetic regions in the Netherlands remains striking (cf. Fig. 2). Across the geogenetic regions, the tenurial regimes led to quite similar morphological outcomes in prehistory, combining areas of more regular parcelling in the form of embanked fields with zones of somewhat less regular division (cf. English 2013, 134-53), albeit still conforming to the overall dominant axes of orientation (cf. Løvschal \& Holst 2014, 8; Brongers 1976, 41). Without downplaying the evident potential for equifinality and inter-site variation in such morphological patterns, it is striking to see what is not there. Fundamentally different systems of land allotment (cf. Jankuhn 1958, 174-5; Bradley 1978, 268; Wickstead 2007, 108; 


\section{S. Arnoldussen. USE-HISTORIES, LATER PREHISTORIC FIELD SYSTEMS IN THE NETHERLANDS}

Gosden 2013; Løvschal 2014, 722-31) - such as larger reclamations of varying shapes, strip-parcelling, or radial or circular bank configurations - are absent in the Dutch corpus of raatakkers, which are mostly rectilinear with quite standardised plot sizes, in parts more aggregate and in others more co-axial in nature. Evidently, those elements of the agricultural system that contributed to the form (eg, initial rectilinear wattle fencing) and inertia (eg, weed dumping or topsoil stripping/manuring leading to bank aggradation) of the raatakker field boundaries were shared or similar across different geogenetic regions. These supraregional similarities reflect a sustainable, successful, and widely shared interplay of boundary conceptualisation, agricultural use, and boundary materialisation which for centuries remained relevant to the farming communities that had initiated and maintained the system's enduring physicality.

Acknowledgements: The Groningen Celtic field programme is indebted to the following organisations for practical, financial, or scientific support: Provincie Drenthe, Gemeente Westerveld, Gemeente Vries, Staatsbosbeheer, Stichting Natuurmonumenten, Provincie Gelderland, Gemeente Ede, Provincie Noord-Brabant, Gemeente Someren, Rijksdienst voor het Cultureel Erfgoed, Nationaal Park De Meinweg, and Stichting Nederlands Museum voor Anthropologie en Praehistorie. Xandra Bardet corrected the English for this paper.

\section{BIBLIOGRAPHY}

Arnold, V. 2011. Celtic Fields und andere urgeschichtliche Ackersysteme in historisch alten Waldstandorten Schleswig-Holsteins aus Laserscan-Daten. Archäologisches Korrespondenzblatt 41, 439-55

Arnoldussen, S. 2008. A Living Landscape: Bronze Age settlement sites in the Dutch river area (2000-800 BC). Leiden: Sidestone

Arnoldussen, S. 2012. Het Celtic field te Zeijen - Noordse veld: kleinschalige opgravingen van wallen en velden van een laat-prehistorisch akkersysteem. Groningen: Grondsporen 16

Arnoldussen, S. 2013. Zoektocht in het zuiden: Celtic fields op ongestuwde afzettingen in Zuid-Nederland. Paleo-aktueel 24, 59-66

Arnoldussen, S. \& Albers, P.C.H. 2015. When urnfields lose their meaning ... The case of Iron Age habitation amidst the Noordbarge urnfield. In E.A.G. Ball \& S. Arnoldussen (eds), Metaaltijden 2. Bijdragen in de studie van de metaaltijden, 149-69. Leiden: Sidestone

Arnoldussen, S. \& Linden, M. vander 2017. Palaeoecological and archaeological analysis of Dutch Celtic fields: Solving the puzzle of Celtic field bank formation. Vegetation History \& Archaeobotany 26(6), 551-70
Arnoldussen, S. \& Scheele, E.E. 2014. De Celtic Fields van Wekerom: kleinschalige opgravingen van wallen en velden van een laat-prehistorisch raatakkersysteem. Groningen: Grondsporen 18

Arnoldussen, S. \& Smit, L. 2017. Zat er nog wat in? Archeobotanisch onderzoek aan een Drentse raatakker. In G. Aalbersberg, M. Schepers \& S.E. Boersma (eds), De Paleo-Palfenier, 53-63. Groningen: Barkhuis

Arnoldussen, S. \& Vries, K.M. de 2014. Of farms and fields: The Bronze Age and Iron Age settlement and Celtic field at Hijken - Hijkerveld. Paleohistoria 55/56(2013/2014), 85-104

Arnoldussen, S. \& Vries, K.M. de 2017. A plan in place? Celtic field habitation at Westeinde (prov. Drenthe, The Netherlands). Lunula Archaeologia Protohistorica 25, 79-89

Arnoldussen, S., Scheele, E.E. \& de Kort, J.W. 2014. Briefrapport verkennend veldonderzoek Celtic field Herkenbosch - 'De Meinweg'. Groningen: Grondsporen 19

Arnoldussen, S., Schepers, M. \& Maurer, A. 2016. Celtic fields in Brabant: wat stuifmeel en zaden kunnen vertellen. Paleo-aktueel 27, 23-31

Becker, C.J. 1971. Früheisenzeitliche Dörfer bei Grøntoft, Westjütland, 3, Vorbericht: Die Ausgrabungen 1967-68. Acta Archaeologica 42, 79-110

Behre, K.-E. 2000. Frühe Ackersysteme, Düngemethoden und die Entstehung der Nordwestdeutschen Heiden. Archäologisches Korrespondenzblatt 30(1), 135-51

Behre, K.-E. 2008. Landschaftsgeschichte Norddeutschlands: Umwelt und Siedlung von der Steinzeit bis zur Gegenwart. Neumünster: Wachholtz Verlag

Bewley, R. 2003. Prehistoric Settlements. Stroud: Tempus

Bewley, R.H., Crutchly, S.P. \& Shell, C.A. 2005. New light on an ancient landscape: Lidar survey in the Stonehenge World Heritage Site. Antiquity 79(305), 636-47

Boer, A.G. de, Laan, W.N.H., Waldus, W. \& Zijverden W.K. van 2008. Lidar-based surface height measurements: Applications in archaeology. In B. Frischer \& A. DakouriHild (eds), Beyond Illustration: $2 D$ and $3 D$ digital technologies as tools for discovery in archaeology, 76-84. Oxford: British Archaeological Report S1805

Bradley, R. 1978. Prehistoric field systems in Britain and north-west Europe - a review of some recent work. World Archaeology 9, 265-80

Broeke, P.W. van den, Fokkens, H. \& Gijn, A.L. van 2005. A prehistory of our time. In L.P. Louwe Kooijmans, P.W. van den Broeke, H. Fokkens \& A.L. van Gijn (eds), The Prehistory of the Netherlands, 17-32. Amsterdam: Amsterdam University Press

Brongers, J.A. 1973. 1833, Reuvens in Drenthe. Een bijdrage tot de geschiedenis van de archeologie / A Contribution to the History of Archaeology. Bussum: Fibula-Van Dishoeck

Brongers, J.A. 1976. Air Photography and Celtic Field Research in the Netherlands. Groningen: Nederlandse Oudheden 6

Casparie, W. 1976. Palynological investigation of the Celtic Field near Vaassen, the Netherlands. In J.A. Brongers (eds), Air Photography and Celtic Field Research in The Netherlands, 105-13. Amersfoort: Nederlandse 
Oudheden: Rijksdienst voor het Oudheidkundig Bodemonderzoek

Clemmensen, N.C. 2010. DHM - den digitale højemodel reliefkortet. In V. Nielsen (eds), Oldtidsagre i Danmark. Sjcelland, Møn og Lolland-Falster, 25-8. Aarhus: Jysk Arkæologisk Selskabs skrifter 71

Cooper, A. 2016. 'Held in place': Round barrows in the later Bronze Age of lowland Britain. Proceedings of the Prehistoric Society 82, 291-322

Curwen, E. \& Curwen, E.C. 1923. Sussex lynchets and their associated field-ways. Sussex Archaeological Collections 64, 1-65

Datema, R.R. 2003. Archeologische monumenten in het Noormansveld in het Nationaal Park Dwingelerveld. Amersfoort: Amersfoort Stichting Archeologische Monumentenwacht Nederland

Devereux, B.J., Amable, G.S., Crow, P. \& Cliff, A.D. 2005. The potential of airborne LIDAR for detection of archaeological features under woodland canopies. Antiquity 305(79), 648-60

English, J. 2013. Pattern and Progress: Field systems of the second and early first millenia $B C$ in southern Britain. Oxford: British Archaeological Report 587

Fens, R.L. \& Arnoldussen, S. 2015. Een opgraving nabij de hunebedden D36 en D37 te Valthe. Groningen: Grondsporen 23

Fokkens, H. 1998. Drowned Landscape: The occupation of the western part of the Frisian-Drenthian Plateau, 4400 $B C-A D$ 500. Assen: Van Gorcum

Fowler, P.J. 1983. The Farming of Prehistoric Britain. Cambridge: Cambridge University Press

Fyfe, R.M., Brück, J., Johnston, R., Lewis, H., Roland, T. \& Wickstead, H. 2008. Historical context and chronology of Bronze Age enclosure on Dartmoor, UK. Journal of Archaeological Science 35, 2250-61

Gaauw, P.G. van der 1989. Aanvullende archeologische inventarisatie "Strabrechtse Heide". Amsterdam: RAAPRapport 31

Gerritsen, F. 2003. Local Identities: Landscape and community in the late prehistoric Meuse-Demer-Scheldt region. Amsterdam: Amsterdam Archaeological Studies 9

Giffen, A.E. van 1918. Begin van een onderzoek van 'de zogenaamde voormalige Romeinsche legerplaats en aangelegen grafheuvelveld te Zeijen. Nieuwe Drentse Volksalmanak 36, 135-75

Giffen, A.E. van 1934. De zgn. heidensche legerplaats te Peest, gem. Norg. Nieuwe Drentse Volksalmanak 52, 110-12

Giffen, A.E. van 1935. Het Ballooër veld ndl. van Balloo, gem. Rolde. Nieuwe Drentsche Volksalmanak 53, 67-116

Giffen, A.E. van 1939. De zgn. heidensche legerplaats te Zuidveld bij Sellingen, gem. Vlachtwedde. Verslag Groninger Museum 1939, 86-93

Giffen, A.E. van 1940. De zgn. Romeinsche of heidensche legerplaats op het Noordsche Veld bij Zeijen, gem. Vries. Nieuwe Drentsche Volksalmanak 58, 200-2

Giffen, A.E. van 1943. Opgravingen in Drente. In J. Poortman (eds), Drente, een handboek voor het kennen van het Drentsche leven in voorbije eeuwen, 391-564. Meppel: Boom \& Zoon
Giffen, A.E. van 1949. Het Noordse Veld bij Zeijen, Gemeente Vries. Opgravingen in 1944. Nieuwe Drentse Volksalmanak 67, 93-148

Giffen, A.E. van 1950. De nederzettingsoverblijfselen in het Bolleveen en de versterking, de zgn. 'legerplaats' aan het Witteveen op het Noordse veld, beide bij Zeijen, gem. Zeijen. Nieuwe Drentsche Volksalmanak 68, 89-122

Glasbergen, W. 1954. Barrow Excavations in the Eight Beatitudes: The Bronze Age cemetery between Toterfout Halve Mijl, North Brabant. II. The Implications. Groningen: Palaeohistoria 3

Gosden, C. 2013. Fields. In S. Bergerbrandt \& S. Sabatini (eds), Counterpoint: Essays in archaeology and heritage studies in honour of Professor Kristian Kristiansen, 111-18. Oxford: British Archaeological Report S2508

Groenman-van Waateringe, W. 1980. Weeds. In M. Ryan (eds), The Origins of Metallurgy in Atlantic Europe: Proceedings of the fifth Atlantic Colloquium Dublin, 30th March to 4th April 1978, 363-8. Dublin: Stationary office

Groenman-van Waateringe, W. 2012. Celtic field banks and Early Medieval rye cultivation. Journal of Archaeology in the Low Countries 4(1), 151-8

Harkel, L. ten, Franconi, T. \& Gosden, C. 2017. Fields, ritual and religion: Holistic approaches to the rural landscape in long term perspective (c.1500 BC-AD 1086). Oxford Journal of Archaeology 36(4), 413-37

Harsema, O.H. 1991. De bronstijd-bewoning op het Hijkerveld bij Hijken. In H. Fokkens \& N. Roymans (eds), Nederzettingen uit de bronstijd en de vroege ijzertijd in de Lage Landen, 21-9. Amersfoort: Nederlandse Archeologische Rapporten 11

Harsema, O.H. 2005. Farms amongst Celtic fields. Settlements on the northern sands. In L.P. Louwe Kooijmans, P.W. van den Broeke, H. Fokkens \& A.L. van Gijn (eds), The Prehistory of the Netherlands (II), 543-55. Amsterdam: Bert Bakker

Hatt, G. 1931. Prehistoric fields in Jylland. Acta Archaeologica 2, 117-58

Heijden, F. van der \& Greving, K. 2009. Visuele inspectie en booronderzoek. In T. Spek, M. Snoek, W.A.B. van der Sanden, M. Kosian, F. van der Heijden, L. Theunissen, M. Nijenhuis, H. Vroon \& K. Greving (eds), Archeologische waardering van Celtic fields in Drenthe, 35-42. Amersfoort: Rapportage Archeologische Monumentenzorg 141

Hermans, C.R. 1865. Noordbrabants Oudbeden. 'sHertogenbosch: Provinciaal Genootschap van Kunsten en Wetenschappen in Noordbrabant

Hesse, R. 2010. LiDAR-derived Local Relief Models (LRM) - a new tool for archaeological prospection. Archaeological Prospection 17, 67-72

Holden, T.G. 1997. Food remains from the gut of the Huldremose bog body. Journal of Danish Archaeology 13(1), 49-55

Humme, A., Lindenbergh, R. \& Sueur, C. 2006. Revealing Celtic fields from LiDAR data using kriging based filtering. In H.G. Maas \& D. Schneider (eds), Proceedings of the ISPRS Commission V Symposium, Dresden, 25-27 September 2006, 1-5. Dresden: ISPRS 


\section{S. Arnoldussen. USE-HISTORIES, LATER PREHISTORIC FIELD SYSTEMS IN THE NETHERLANDS}

Jankuhn, H. 1958. Ackerfluren der Eisenzeit und ihre Bedeutung für die frühe Wirtschaftsgeschichte. Berichte der Römisch-Germanischen Kommission 37/38(1956/ 1957), 148-214

Janssen, L.J.F. 1848. Drenthsche Oudheden. Utrecht: Kemink \& Zoon

Johnston, R. 2005. Pattern without a plan: Rethinking the Bronze Age coaxial field systems on Dartmoor, South-West England. Oxford Journal of Archaeology 24(1), 1-21

Johnston, R. 2013. Bronze Age fields and land division. In H. Fokkens \& A.F. Harding (eds), Oxford Handbook of the European Bronze Age, 311-27. Oxford: Oxford University Press

Klamm, M. 1993. Aufbau und Entstehung eisenzeilicher Ackerfluren ('Celtic Fields'). I Stand der Forschung. Göttingen: Göttinger Bodenkundliche Berichte 102

Klaveren, H.W. van 1986. Celtic Field en nederzettingssporen bij de Vijfsprong, gemeente Ede. Unpublished MA thesis, Leiden University

Kooi, P.B. \& Langen, G.J. de 1987. Bewoning in de vroege ijzertijd op het Kleuvenveld te Peelo, gem. Assen. Nieuwe Drentse Volksalmanak 104, 151-65

Kooistra, M.J. \& Maas, G.J. 2008. The widespread occurrence of Celtic field systems in the central part of the Netherlands. Journal of Archaeological Science 35, 2318-28

Kortlang, F. \& Ginkel, E. van 2016. Voordat Someren Someren werd. Archeologie van een dekzandeiland. Utrecht: Matrijs

Kroll, H.J. 1987. Vor- und frühgeschichtliche Ackerbau in Archsum auf Sylt: Eine botanische Grossrestanalyse. In G. Kossack, O. Harck \& J. Reichstein (eds), Archsum auf Sylt, 2: Landwirtschaft und Umwelt in vor- und frühgeschichtlicher Zeit, 51-158. Mainz am Rhein: Römisch-Germanische Forschungen 44

Liversage, D., Munro, M.A.R, Courty, M.-A. \& Nørnberg, P. 1985. Studies of a buried Iron Age field. Acta Archaeologica $56,55-84$

Liversage, D. \& Robinson, D. 1993. Prehistoric settlement and landscape development in the sandhill belt of southern Thy. Journal of Danish Archaeology 11, 39-56

Lohof, E. \& Roessingh, W. 2014. The Westfrisian Bronze Age: A view from Enkhuizen-Kadijken. Journal of Archaeology in the Low Countries 5(1), 51-78

Løvschal, M. 2014. Emerging boundaries: Social embedment of landscape and settlement divisions in Northwestern Europe during the first millennium BC. Current Anthropology 55(6), 725-50

Løvschal, M. 2015. Lines of landscape organisation: Skovbjerg Moraine (Denmark) in the first millennium BC. Oxford Journal of Archaeology 34(3), 259-78

Løvschal, M. \& Holst, M.K. 2014. Repeating boundaries: Repertoires of landscape regulations in southern Scandinavia in the Late Bronze Age and Pre-Roman Iron Age. Danish Journal of Archaeology 3(2), 95-118

McIntosh, J. 2009[2006]. Handbook to Life in Prehistoric Europe. Oxford: Oxford University Press

Meylemans, E., Creemers, G., De Bie, M. \& Paesen, J. 2015. Revealing extensive protohistoric field systems through high resolution LIDAR data in the northern part of Belgium. Archäologisches Korrespondenzblatt 45, 197-213

Müller-Wille, M. 1965. Eisenzeitliche Fluren in den festländische Nordseegebieten. Reihe Siedlung und Landschaft in Westfalen 5. Münster: Landeskundliche Karten und Hefte der Geographischen Kommission für Westfalen

Odgaard, B.V. 1985. A pollen analytical investigation of a Bronze Age and Pre-Roman Iron Age soil profile from Grøntoft, Western Jutland. Journal of Danish Archaeology 4(1), 121-8

Picardt, J. 1660. Korte beschryvinge van eenige vergetene en verborgene Antiquiteten der Provintien en Landen tusschen de Noord-Zee, de Yssel, Emse en Lippe. Amsterdam: Tymon Houthaak

Sanden, W.A.B. van der 2009. Celtic fields in Drenthe: Een overzicht van 350 jaar onderzoek. In T. Spek, M. Snoek, W.A.B. van der Sanden, M. Kosian, F. van der Heijden, L. Theunissen, M. Nijenhuis, H. Vroon \& K. Greving (eds), Archeologische waardering van Celtic fields in Drenthe, 15-24. Amersfoort: Rijksdienst voor het Cultureel Erfgoed 141

Sanden, W.A.B. van der 2012. Gids voor de hunebedden in Drenthe en Groningen. Zwolle: WBOOKS

Schrijver, P. 2011. Niet enkel ruiten en raten. Een analyse van de culturele informatie die besloten ligt in de ruimtelijke morfologie van Nederlandse Celtic fields. Unpublished BA thesis, Groningen University

Sharples, N. 2010. Social Relations in Later Prehistory: Wessex in the first millennium BC. Oxford: Oxford University Press

Smith, G. 1996. Archaeology and environment of a Bronze Age cairn and prehistoric and Romano-British field system at Chysauster, Gulval, near Penzance, Cornwall. Proceedings of the Prebistoric Society 62, 167-219

Spek, T., Groenman-van Waateringe, W., Kooistra, M. \& Bakker, L. 2003. Formation and land-use history of Celtic fields in north-west Europe - An interdisciplinary case study at Zeijen, the Netherlands. European Journal of Archaeology 6(2), 141-73

Spek, T., Snoek, M., Sanden, W.A.B. van der, Kosian, M., Heijden, F. van der, Theunissen, L., Nijenhuis, M., Vroon, H. \& Greving, K. 2009. Archeologische waardering van Celtic fields in Drenthe. Amersfoort: Rapportage Archeologische Monumentenzorg 141

Stuart, P. 1977. Gewoon aardewerk uit de Romeinse Legerplaats en de bijbehorende grafvelden te Nijmegen. Leiden: Oudheidkundige Mededelingen uit het Rijksmuseum van Oudheden te Leiden Supplement 43

Taayke, E. 1996. Die einheimische Keramik der nördlichen Niederlande, 600 v.Chr. bis 300 n.Chr., Teil II: Drenthe. Berichten van de Rijksdienst voor het Oudheidkundig Bodemonderzoek 41, 9-102

Vanmontfort, B., Langohr, R., Marinova, E., Nicosia, C. \& Van Impe, L. 2015. Een archeologische evaluatie en waardering van Celtic Fields in het Kolisbos (Neerpelt, provincie Limburg). Leuven: EPA-Rapport 50

Voskuilen, E., Reimann, T. \& Wallinga, J. 2016. NCL-71315 Quartz Luminescence Dating Report 
Someren - De Hoenderboom. Wageningen: Netherlands Centre for Luminescence Dating

Wallinga, J. \& Versendaal, A.J. 2013a. NCL-7212 Quartz Luminescence Dating Report Zeijen - Noordse veld. Wageningen: Netherlands Centre for Luminescence Dating

Wallinga, J. \& Versendaal, A.J. 2013b. NCL-7213 Quartz Luminescence Dating Report Wekerom - Lunteren. Wageningen: Netherlands Centre for Luminescence Dating

Waterbolk, H.T. 1949. Palynologisch onderzoek van grafheuvels en oud akkerland op het Noordse Veld bij Zeijen. Nieuwe Drentse Volksalmanak 67, $126-47$

Waterbolk, H.T. 1977. Opgravingen rond het Witteveen op het Noordse Veld bij Zeijen, gem. Vries (1949-1953). Nieuwe Drentse Volksalmanak 94, 5(177)-31(203)

Wickstead, H. 2007. Theorizing tenure: Land division and identity in later prehistoric Dartmoor, South-West Britain. Unpublished PhD thesis, UCL
Wijk, B.L.M. van 2015. Prehistoric tenure and inheritance. Unpublished BA thesis, Groningen University

Yates, D.T. 2007. Land, Power and Prestige: Bronze Age field systems in southern England. Oxford: Oxbow Books

Zeist, W. van 1955. Pollen analytical investigations in the northern Netherlands, with special reference to archaeology. Acta Botanica Neerlandica 4(1), 1-81. Amsterdam: Universiteit van Amsterdam. Available at: https://doi.org/10.1111/j.1438-8677.1955.tb00316.x

Zimmermann, W.H. 1976. Die eisenzeitlichen Ackerfluren Typ 'Celtic Field' von Flögeln-Haselhörn, Kr. Weser Münde. Probleme der Küstenforschung im südlichen Nordseegebiet 11, 79-100

Zimmermann, W.H. 1995. Ackerbau in ur- und Frühgeschichtlicher Zeit auf der Geest und in der Marsch. In H.-E. Dannenberg \& H.-J. Schulze (eds), Geschichte des Landes zwischen Elbe und Weser, 28-9315. Stade: Schriftenreihe des Landschaftsverbandes der ehemaligen Herzogtümer Bremen und Verden 7

\section{RÉSUMÉ}

Les champs qui ont survécu aux Celtes: Histoires de l'usage des systèmes de champs de la fin de la préhistoire (champs celtiques ou Raatakkers) aux Pays-Bas, de Stijn Arnoldussen

Le programme de recherches des champs celtiques de l'université de Groningen implique des fouilles de recherches des champs celtiques néerlandais ou Raatakkers: des parcelles de champs encaissées, sensées dater de l'âge du fer (env. 800 av.J.C.-12 av.J.C. cal ). Dans cet article, nous accordons une attention méticuleuse à (a) la paléoécologie des Raatakkers; (b) la relation entre habitat et agriculture dans de tels systèmes; et (c) leurs datation et durée d'utilisation. Contrairement à notre intuition, on argumente que les macro vestiges de récoltes tels que l'orge, le froment, le millet et le lin recueillis dans les talus des champs celtiques représentent un signal non local (occupation) plus qu'ils ne documentent les régimes agricoles locaux. Des approches palynologiques, dans lesqelles un signal plus local peut être préservé mais qui mettent aussi en évidence des témoignages de détails du régime agricole tels que des stratégies de fumage et des cycles de jachère sont considérées comme étant des voies appropriées. Une discussion des relations entre habitat et agriculture montre que les emplacements de maisons découverts à l'intérieur des champs celtiques néerlandais sont presque invariablement situésdans des positions qui débordent en partie sur le talus. De plus, dans la plupart des cas de telles traces d'occupation semblent dater de l'âge du fer moyen ou tardif, ce qui soulève la question de savoir où habitaient les premiers agriculeurs des champs celtiques, puisque les communautés qui les conçurent et furent les premières à utiliser ces champs celtiques prédataient probablement l'âge du fer. Une revue critique des dates existantes et une discussion des nouvelles dates OSL et SMA a montré que la construction du talus des champs celtiques néerlandais commença autour des 13-10 èmes siècles av.J.C.cal. et continua jusque dans l'ère romaine. Les chronostratigraphies préservées dans les talus témoignent d'un régime agricole viable d'une longévité et profondeur d'utilisation sans précédent: des siècles d'utilisation continue font du systéme qui utilise les Raatakkers, la forme la plus durable et la plus stable d'agriculture connue de l'histoire des Pays-Bas.

\section{ZUSSAMENFASSUNG}

Die Felder, die die Kelten überlebten: Die Nutzungsgeschichte frühgeschichtlicher Feldsysteme (Celtic Fields oder Raatakkers) in den Niederlanden, von Stijn Arnoldussen

Das Celtic Field Forschungsprogramm der Universität Groningen schließt Forschungsgrabungen niederländischer Celtic Fields oder raatakkers ein: umwallte Ackerflächen, die in die Eisenzeit datieren sollen (ca. $800 \mathrm{cal}$ BC bis 12 BC). Der vorliegende Beitrag widmet sich intensiv (a) der Paläoökologie der raatakkers; (b) der 


\section{S. Arnoldussen. USE-HISTORIES, LATER PREHISTORIC FIELD SYSTEMS IN THE NETHERLANDS}

Beziehung zwischen Besiedlung und Landwirtschaft in solchen Systemen; und (c) ihrer Datierung und Nutzungsgeschichte. Entgegen der naheliegenden Vermutung wird hier angenommen, dass die Makroreste von Feldfrüchten wie Gerste, Weizen, Hirse und Leinen, die aus Begrenzungswällen der Celtic Fields geborgen wurden, ein nicht-lokales (Siedlungs-) Signal darstellen statt lokalen Ackerbau zu belegen. Palynologische Untersuchungen, in denen ein stärker lokales Signal erhalten sein kann, die aber auch Hinweise auf Details der Landwirtschaftsweise aufzeigen wie Strategien der Düngung und Bracheperioden, werden als geeigneter Weg vorgestellt. Eine Diskussion des Zusammenhangs zwischen Besiedlung und Ackerbau zeigt, dass Standorte von Häusern, die innerhalb von niederländischen Celtic Fields freigelegt wurden, nahezu regelhaft so positioniert sind, dass sie Wälle überlappen. Darüber hinaus datieren diese Siedlungsspuren offenbar in den meisten Fällen in die Mittlere bis Späte Eisenzeit, was die Frage aufwirft, wo die ursprünglichen Bauern der Celtic Fields wohnten, da die Gemeinschaften, die die Celtic Fields planten und zuerst nutzten, wahrscheinlich vor die Eisenzeit datieren. Eine kritische Bewertung vorliegender Daten und die Diskussion neuer OSL- und AMS-Daten hat gezeigt, dass die Errichtung der Wälle niederländischer Celtic Fields um das 13.-10. Jahrhundert cal Bс begann und bis in die Römische Eisenzeit fortdauerte. Die in den Wällen erhaltenen Chronostratigraphien belegen eine nachhaltige Ackerbauweise von beispielloser Zeittiefe: Jahrhunderte kontinuierlicher Nutzung machen das System der Verwendung von raatakkers die dauerhafteste und stabilste Form der Landwirtschaft, die in der Geschichte der Niederlande bekannt ist.

\section{RESUMEN}

Los campos que sobrevivieron a los celtas: las historias de uso de los sistemas de cultivo en la Prehistoria Reciente (campos celtas o Raatakkers) en los Países Bajos, por Stijn Arnoldussen

El programa de investigación centrado en los campos de cultivo celtas de la Universidad de Groningen incluye la excavación de campos de cultivo celtas holandeses o raatakkers: parcelas de campo aterrazadas datadas en la Edad del Hierro ( 800 cal BC-12 BC). En este artículo, se presta una atención detallada a (a) la paleoecología de los raatakkers; (b) la relación entre los lugares de habitación y la agricultura en estos sistemas; y (c) su datación y uso. En contra de lo que se pueda intuir, se sostiene que los macrorrestos de cultivos como la cebada, el trigo, el mijo y el lino recuperados en estos campos celtas representan una evidencia no local (de asentamiento) en vez de constituir un reflejo de los sistemas agrícolas locales. Las aproximaciones palinológicas, en las que se preserva un registro local pero que también evidencian ciertos detalles del sistema agrícola, como las estrategias de abono y los ciclos de barbecho, se proponen como los enfoques más apropiados. La discusión sobre las relaciones entre lugares de habitación y agricultura refleja que, casi invariablemente, las viviendas documentadas dentro de los campos celtas holandeses se sitúan parcialmente superpuestas a los aterrazamientos. Además, en la mayor parte de los casos estas trazas de asentamiento se datan a mediados o finales de la Edad del Hierro, lo que plantea la cuestión de dónde habitaban los primeros agricultores de los campos celtas ya que las comunidades que planificaron y usaron inicialmente estos campos probablemente fueran anteriores a la Edad del Hierro. Una revisión crítica de las dataciones existentes y una discusión de las nuevas fechas de OSL y AMS refleja que la construcción de estos campos celtas holandeses comienza posiblemente en los siglos XIII-X cal BC y continúa hasta época romana. Las cronoestratigrafías conservadas en los aterrazamientos dan testimonio de un régimen agrícola sostenible con una profundidad temporal sin precedentes: siglos de uso continuado hacen del sistema empleado en los raatakkers la forma más duradera y estable de agricultura conocida en la historia de los Países Bajos. 